\title{
Banding of Oedionychina (Coleoptera:Alticinae) Chromosomes: C- and Ag-bands ${ }^{1}$
}

\author{
Niilo Virkki²
}

\begin{abstract}
Banding of chromosomes was studied in about 40 species of Brazilian Oedionychina. Long sex chromosomes and large germ line cells of these fleabeetles facilitate such studies. Because the sex chromosomes comprise about $50 \%$ of the total karyotype length and do not pair in male meiosis, the spermatogenesis serves unusually well for the banding purposes. Abundant mitoses are obtained from colchicinized embryos (eggs).

Conventional tapping and smearing techniques are catastrophic, because the large spermatocytes are so perishable. Squashes of Kahle-Smith-fixed tissues are safest and good for silver staining, but the fixative tends to slow down the formation of C-bands. Teasing the testes with pins on the slide saves about $25 \%$ of the MI cells.

C-bands mark procentric heterochromatin in most chromosomes, and intercalary heterochromatin of variable amount and location in the sex chromosomes. Insufficient treatment in $\mathrm{Ba}(\mathrm{OH})_{2}$ induces G-band-like marking of the sex chromosomes (especially of $\mathrm{Y}$ ) in some species. Failure of $\mathrm{C}$-banding can be corrected by rebandings up to 6 times. A prolonged Giemsa staining is necessary for rebanded chromosomes.

Silver staining marks kinetochore dots in most chromosomes, and intercalary bands in male diplotenic sex chromosomes. Strongest of these bands are still present at MII. The active sites they mark are presumably related to a synthesis (through gene amplification?) of a material structurally similar to chromatoid bodies.

Band differences between species show that $\mathrm{C}$ - and $\mathrm{Ag}$-bands are powerful tools for the cytotaxonomy of these beetles. Ag-bands must be compared with care, because their number is reduced from diplotene to MI.
\end{abstract}

\section{INTRODUCTION}

The complicated architecture of Eukaryote chromosomes permits variation of the karyotype structure without much coinciding variation in genotype or phenotype, and vice versa. This has caused much confusion in the cytotaxonomy. The new banding methods (2) promise improved identification of the chromosomes for taxonomic and phylogenetic purposes.

The impact of these new methods on the genetics and phylogeny has already been great, but it is not equally shared by all Eukaryota. The

${ }^{1}$ Manuscript submitted to Editorial Board February 25, 1982.

${ }^{2}$ Cytogeneticist, Agricultural Experiment Station, College of Agricultural Sciences, University of Puerto Rico, Mayagüez Campus, Wio Piedras, P.R. This work was done during the sabbatical leave of the author, spent at the Rio Claro campus of the Universidade Estadual Paulista "Julio de Mesquita Filho" (UNESP) in Brazil. Additional support was obtained from the Fundação de Amparo à Pesquisa do Estado de São Paulo. The author wishes to express his gratitude to these institutions, as well as to the colleagues at Rio Claro, especially to the Campus President, Prof. Dr. Amilton Ferreira, who helped in every way. 
field that has most benefited is medicine, where most personnel, facilities, and funds have been available. Systematically, this means preferably Mammalia, and man. Today the majority of the cytogeneticists are human cytogeneticists, busy with routine or fundamental analysis of the human karyotype. Imponent results on chromosomal structure in relation to inherent syndromes and phylogeny $(14,19,23)$ have already been accumulated. The invertebrates have been studied much less, and most of the vast field of insect systematics is still void of these new and precise identification methods.

Ennis ( 5 to 9) pioneered in banding of the beetle chromosomes. His results are particularly interesting, because he has checked the species of Chilocorus and Pissodes, analyzed earlier by S. G. Smith, who used other methods.

In most Chilocorus spp., Giemsa, quinacrine, and trypsin techniques are incapable of discriminating between the euchromatic and heterochromatic (= dispensable) arms. Only in Ch. stigma diphasics are the heterochromatic arms marked by 2 to 4 small bands, the number depending on the technique and also on the individual beetle. Similarly, in Pissodes rotundatus an arm, considered by Smith (32) to be a heterochromatic accretion product, shows no fluorescence when stained with quinacrine. Consequently, there is a category of chromatin which is heterochromatin by the genetic criterion, but remains "cryptic" (33) by the banding criteria. Ennis, admittedly, did not use all banding methods, but he used the most important ones.

Procentric heterochromatin of Chilocorus, weakly developed in stigma and generally replicating later than the dispensable arm of the diphasic autosomes, shows more diversity. In some chromosomes, Giemsa stains it entirely; in others, only a strong paracentric band appears. Quinacrine reveals more diffuse bands, usually covering the entire block. The number of these differentially marked autosomes helps in delimiting the Chilocorus taxa.

Later Ennis (7) showed that bands the reverse of those of quinacrine can be induced in Chilocorus by the Feulgen stain, if the hydrolysis is prolonged.

In the Coccinellid Egius platycephalus, Ennis (9) found size differences between the quinacrine-positive procentric blocks of the homologues. This means diversity in the procentric heterochromatin among individuals, due, probably, to hybridization between demes, if not to frequent rearrangements or accretion of the centric block.

Rees et al. (27) have shown that heterochromites which they identified by other methods in Dermestes spp. stain intensely with $\mathrm{C}$-banding techniques. A couple of species are distinguished by a pattern of band distribution quite specific for each of them, the remainder of species 
being more similar among themselves. G-banding (based on chromomeres: 3) produced patterns so specific that interspecific comparison was not possible, at least not in the small sample of species they studied. In one species (maculatus), Q-banding marked a series of smaller bands within the heterochromatin, and this pattern was confirmed by Gbanding also.

Vidal \& Giacomozzi (35) found procentric C-bands in all autosomes and the X chromosome of Enema pan (Scarabaeidae), the Y chromosome being totally marked. In another scarab, Bolbites ornitoides, the results were a little more complex (34). Only one pair of autosomes was marked by C-banding as in E. pan. In 8 pairs of "naturally diphasic" autosomes, the heterochromatic arms were totally marked (contra diphasics induced in Chilocorus: 30); and inversion of one of these autosomes was also found.

Postiglioni and Brum-Zorrilla briefly reported on a successful marking of pericentromeric heterochromatin in the Chrysomelids Botanochara angulata, two species of Chelymorpha (24), and Calligrapha polyspila (25). In the latter, fluorescent banding stains were also applied.

In the Oedionychina fleabeetles, the large sex chromosomes are especially inviting for banding analysis. In many species these chromosomes show much structural character even by the classical preparation techniques. The $\mathrm{Y}$ chromosome of Alagoasa bicolor (41) as well as the $\mathrm{X}$ of Omophoita superba (38) has a natural gap in one of its arms. The distal ends of $\mathrm{Y}$ and/or X of some Omophoita spp. are suspected of droplet nucleolus assembly in the diffuse diplotene. They condense late but intensely (33, p. 144). Omophoita superba shows a rather stretchable centric gap in its X (38). One of the arms of both X and Y condenses precociously in Walterianella spp. (33, p. 138; 37). Fifty Oedionychina species have been studied, but as yet only Omophoita cyanipennis F. has been banded (33, p. 52). The $\mathrm{X}$ chromosome looks rather diffuse by quinacrine, but $\mathrm{Y}$ shows one proximal and one distal band in the short arm, and 3 distal bands in the long arm.

This exhausts the survey of chromosome banding in Coleoptera. The scarce results accumulated seem promising for cytotaxonomical studies. As to the Oedionychina especially, there is a reasonable hope that banding of the large sex chromosomes will significantly contribute to the systematics of these fleabeetles. The present study concerns application of Cbanding and silver (NOR) techniques to Oedionychina.

\section{MATERIALS AND METHODS}

The material consists of about 40 species of Oedionychina. Only four of them are properly identified at the present (thanks are due for this identification to Mrs. Bohumila Bechyně, Instituto de Zoologia Agricola, 
Universidad Central de Venezuela, Maracay, Venezuela), and cytotaxonomic considerations are limited to them: Alagoasa januaria Bech., Omophoita annularis Ill., O. octoguttata F., and O. personata Ill. The beetles were collected from the surroundings of the city of Rio Claro (São Paulo, Brazil). Most of them came from the experimental forest "Edmundo Navarro de Andrade," where the somewhat abandoned plantations of Eucalyptus, Pinus, and other trees, allow proliferation of the ground vegetation. Much scantier a beetle yield was obtained from the cerrados and from a residual natural high forest in a fazenda, São José. Some beetles were collected in Serra de Mantiqueira, above the city of Piquete, São Paulo.

The beetles were transported and kept overnight in plastic bags, and prepared the next day.

Good C-bands were induced by Vidal \& Virkki (36) in Oedionychina chromosomes using the short method of Vidal \& Giacomozzi (35), which is close to that of Deavan (4). Because the source may not be easily available to all readers, the method is also given here (Schedule 1). Experimenting with different phases of $\mathrm{C}$-banding could not be performed in the short steps of these methods; thus the final recommendation (Schedule 8) turned out different from but not necessarily always better than the above mentioned methods.

Since Goodpasture \& Bloom (12) published their silver method for marking NORs, numerous similar techniques have appeared. Most of them were tried in Rio Claro and found inadequate because of dirty and inconstant results. The only method that produced reasonably clean results in Oedionychina was that of Pathak (Schedule 2).

Details of the methods are given in the following chapter, and in Protocols and Schedules.

Magnification of the illustrations is $1440 \times$, except for the general picture of figure 1 , where it is $560 \times$.

\section{RESULTS AND DISCUSSION C-BANDING}

A foreign lecturer came to a Brazilian university to show how C-bands are made. A detailed procedure of the most famous French banders was carefully followed. No C-bands appeared. In evaluating the failure, all details of the procedure were once again followed up, and found to be exactly as in the original work. Except for one: they did not use the water of Paris.

(An anecdote lingering in the Brazilian universities).

Authors rarely describe the failure they experience before satisfactory results are obtained, nor do they always give an idea on the reliability and repeatability of the procedure finally chosen. Thus, although it is claimed that C-bands are safely produced with any of the most common 


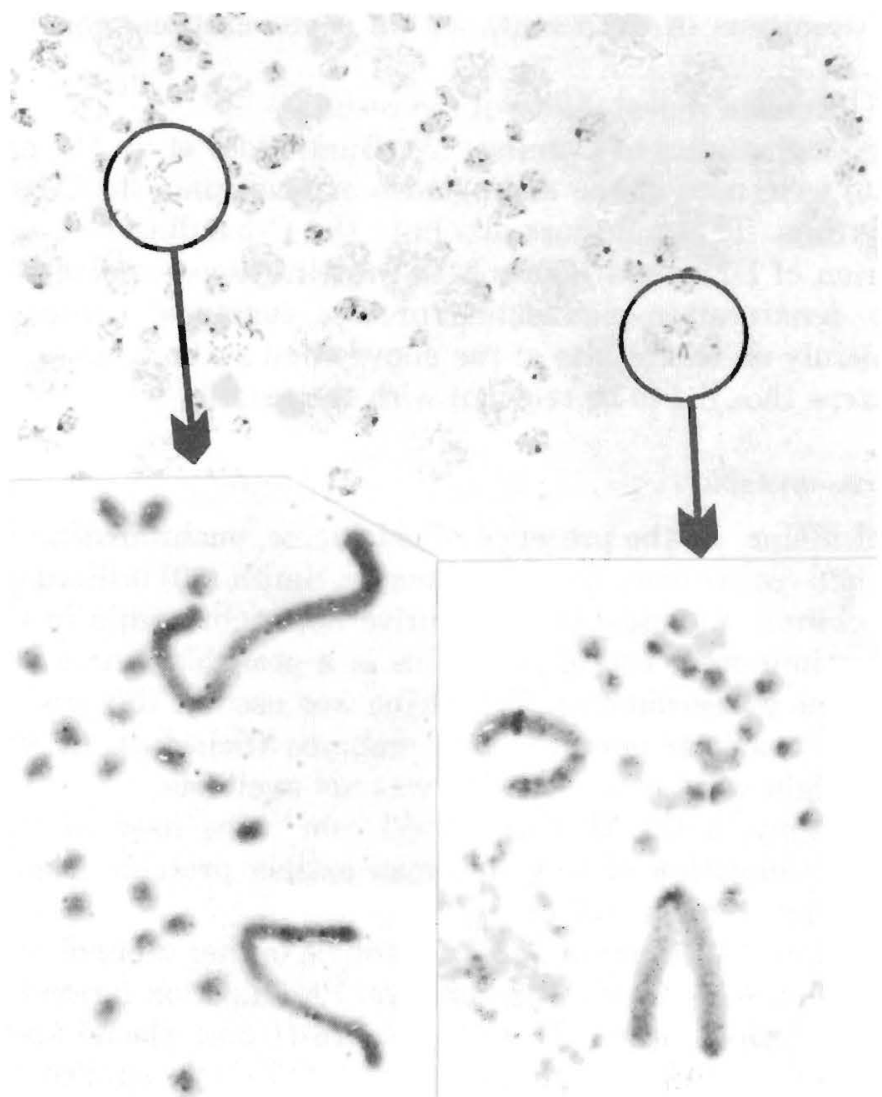

FrG. 1.-Omophoita octoguttata. Mosaicism in C-banding (Protocol 6). The spermatogonial metaphases, circled in the general picture, shown in higher magnification below. The right plate shows bands (karyogrammed in fig. $3 \mathrm{C}$ ), the left one, none. The distance between these metaphase plates is about $100 \mu \mathrm{m}$.

procedures, nothing is farther from reality. Although some taxons (like Mammals) seem to band regularly after standardized rearing (esp. tissue culture), others do not follow suit. Therefore, the C-banders tend to suspect every step of the procedure, especially the one they usually control least: the stock solution of the Giemsa stain. They try to standardize as many steps as they dare, varying the few they believe are most important for the results.

The four common failures are:

1. Chromosomes unstained or understained, with no bands, or too little contrasted bands.

2. Chromosomes too dark, with no bands, or too little contrasted bands. 
3. Mosaicism of the results within a preparation (Fig. 1, Protocol 1).

4. Uncertain repeatability of the results.

Theoretical studies of Comings (3), Burkholder et al. (1), and Holmquist (16) were used as the main guides in developing the C-banding for Oedionychina. These authors attribute the C-banding to a differential destruction of DNA and higher MW proteins associated with it, rather than to denaturation-reannealing process suggested earlier. Table 1, based mainly on the results of the above cited authors, gives the preparation steps thought to be relevant with the results.

\section{Comments on table 1}

1. Colchicine. In the presence of colchicine, euchromatine condenses earlier than constitutive heterochromatin. Smith (30) utilized this difference to delimit unbandable constitutive heterochromatin in Chilocorus. An indiscriminatory use of colchicine is a probable source of errors in chromosome measurements. Colchicine was used in this study to arrest mitoses in ovariolar germaria and embryos (Schedule 3). Vincaleucoblastine might work safer (13), but was not available.

2. Hypotony. $0.075 \mathrm{M} \mathrm{KCl} \mathrm{(10-60} \mathrm{min.)} \mathrm{was} \mathrm{used} \mathrm{in} \mathrm{the} \mathrm{present}$ studies. Prolongation of this step may extract proteins from the cells, adding to the "tortilla" effect.

3. Fixation. 10-60 min. in acetic alcohols (either ethanol or methanol as alcohol) at $+25^{\circ} \mathrm{C}$, with one change. Prolongation beyond this time, when unavoidable, at $+4^{\circ} \mathrm{C}$. Kahle-Smith (1 part glacial acetic acid: 3 parts formalin (40\%): 7.6 parts ethanol (95\%)) is applied for 2 to 4 (seldom up to 10) minutes, depending on the size of the tissue piece. Fixation in acetic alcohols high in acetic acid, or plain $45 \%$ or $60 \%$ acetic acid, helps spreading the testis tissue by needles, and has produced satisfactory bands.

4. HCl. Unnecessary for Oedionychina, if above mentioned fixatives are used. Possibly the water content of the tissue is sufficient for depuration during the acetic alcohol fixations.

5. $\mathrm{Ba}(\mathrm{OH})_{2}$. Unfiltered, saturated solution made and used at $30^{\circ} \mathrm{C}$. Thereafter, preparations dipped 1-2 times in $0.2-\mathrm{N} \mathrm{HCl}$, then washed in distilled water. $\mathrm{HCl}$ eliminates rests of $\mathrm{Ba}(\mathrm{OH})_{2}$ and $\mathrm{BaCO}_{3}$, but does not affect the banding if time is not prolonged beyond one minute.

6. Alkalinization of the saline depends on the kind of glass surface covered. Using 2 XSSC in a common 8 -slot coupling jar without preparations in Puerto Rico, the $\mathrm{pH}$ jumped from 7.0 to 8.3 in one hour at $65^{\circ}$ C. Repetition of the experiment with another similar jar in Rio Claro showed a shift from $\mathrm{pH} 7.1$ to 8.6. To minimize the alkalinization, glass 
TABLE 1.-Effects of the main steps of C-banding in DNA and associated proteins

\begin{tabular}{|c|c|c|c|}
\hline Step & DNA & Proteins & Remarks \\
\hline 1. Colchicine & $\begin{array}{l}\text { Changes in length } \\
\text { proportion of eu- } \\
\text { heterochromatin }\end{array}$ & & Smith (30) \\
\hline 2. Hypotony & Fragmentation & & \\
\hline \multicolumn{4}{|l|}{ 3. Fixation } \\
\hline a. 1:3 (eth.) & $\begin{array}{l}\text { Fragmentation, de- } \\
\text { purination }\end{array}$ & & $\begin{array}{l}\text { Depurination only } \\
\text { when water } \\
\text { present }\end{array}$ \\
\hline b. $1: 3$ (meth.) & $\begin{array}{l}\text { Fragmentation, de- } \\
\text { purination }\end{array}$ & Eliminates histones & $\begin{array}{l}\text { Depurination only } \\
\text { when water } \\
\text { present }\end{array}$ \\
\hline c. Kahle-Smith & $\begin{array}{l}\text { Fragmentation, de- } \\
\text { purination }\end{array}$ & $\begin{array}{l}\text { Irreversible harden- } \\
\quad \text { ing }\end{array}$ & $\begin{array}{l}\text { Formalin does af- } \\
\text { fect depurination. } \\
\text { Aging also hard- } \\
\text { ens }\end{array}$ \\
\hline 4. $\mathrm{HCl} 0.2 N$ & $\begin{array}{l}\text { Depurination, some } \\
\text { denaturation }\end{array}$ & $\begin{array}{l}\text { Extracts some his- } \\
\text { tones, and non- } \\
\text { histones, reduces } \\
\text { extraction of his- } \\
\text { tones in } 5 \text {. }\end{array}$ & $\begin{array}{l}\text { Necessary if } 2 \text {. and } \\
\text { 3. are short }\end{array}$ \\
\hline 5. $\mathrm{Ba}(\mathrm{OH})_{2}$ & $\begin{array}{l}\text { Irreversible dena- } \\
\text { turation, some } \\
\text { breakage at apu- } \\
\text { rinic sites. More } \\
\text { gentle than } \\
\mathrm{NaOH}\end{array}$ & $\begin{array}{l}\text { Extracts many non- } \\
\text { histones and } \\
\text { some histones. } \\
\text { More severe than } \\
\mathrm{NaOH}\end{array}$ & $\begin{array}{l}\text { Prolongation ex- } \\
\text { tracts the re- } \\
\text { maining non-his- } \\
\text { tones }\end{array}$ \\
\hline 6. Hot saline & $\begin{array}{l}\text { Breakage at apu- } \\
\text { rinic sites, ex- } \\
\text { traction of frag- } \\
\text { ments }\end{array}$ & Little effect & $\begin{array}{l}\text { Alcalinization due } \\
\text { to glass }\end{array}$ \\
\hline 7. Giemsa & $\begin{array}{l}\text { Stacking at } \mathrm{P} \text { sites } \\
\text { of DNA; meta- } \\
\text { chromasy }\end{array}$ & Does not stain & \\
\hline $\begin{array}{l}\text { 8. Washing in } \\
\text { water or buffer }\end{array}$ & $\begin{array}{l}\text { Progressive deco- } \\
\text { loration, rapid in } \\
\text { buffer }\end{array}$ & & \\
\hline
\end{tabular}

jars were replaced by tubiform, heat-resistant plastic jars made by LABORLEX, São Paulo. The saline 2XSSC was substituted by Holmquist's saline (phosphate buffer adjusted to $\mathrm{pH} 7.3$, then EDTA added until 3 $\mathrm{mM}$ strong). These conditions guarantee an unaltered $\mathrm{pH}$ of the solution of a fully charged tube at least for $3 \mathrm{~h}$ at $65^{\circ} \mathrm{C}$.

7. Staining. Giemsa is the most controversial agent of the C-banding. Most banders agree that the quality of the stock solution is of prime importance, but beyond that statement, there is a kaleidoscopic variety of opinions. 
The brand is one factor. Merck and Gurr R66 (the latter not available in Brazil) are usually accepted, but Webb (43) prefers one produced by Bio-Science Laboratories Pty. Ltd., Melbourne, Australia. According to Kimber et al. (18), the maximum age of the stock solution is 1-2 months, but I have made good bands using the last drops of an English (label undecipherable) stock solution bought by Prof. A. Mesa 6 years ago in Australia, and kept since unrefrigerated in Rio Claro.

The proportion of glycerine to methanol varies much in the stock solutions, for instance:

\begin{tabular}{|c|c|c|c|}
\hline $1 \mathrm{~g}$ Giemsa powder & $40 \mathrm{ml}$ glycerine & $60 \mathrm{ml}$ methanol & $\begin{array}{l}\text { (a solution found in Rio } \\
\text { Claro) }\end{array}$ \\
\hline $1 \mathrm{~g}$ Giemsa powder & $54 \mathrm{ml}$ glycerine & $84 \mathrm{ml}$ methanol & $\begin{array}{l}\text { (recommended by } \\
\text { Merck) }\end{array}$ \\
\hline $1 \mathrm{~g}$ Giemsa powder & $66 \mathrm{ml}$ glycerine & $66 \mathrm{ml}$ methanol & Kimber et al. (18) \\
\hline $1 \mathrm{~g}$ Giemsa powder & $66 \mathrm{ml}$ glycerine & $34 \mathrm{ml}$ methanol & $\begin{array}{l}\text { (VEAFARM, São } \\
\text { Paulo) }\end{array}$ \\
\hline
\end{tabular}

The staining solution is made $3-4 \%$ strong (Webb (43) uses $7-17 \%$ for grasshoppers) in phosphate buffer of $\mathrm{pH}$ 6.9. Vidal and Giacomozzi (35) used this buffer diluted to $4.3 \%$. The stock solution must be first well shaken to resuspend all precipitates.

Diluted solutions older than $30 \mathrm{~min}$. are useless according to Webb (43). Such a rapid spoiling is due to a pellicle forming on the top of the solution. The pellicle sticks to the preparations irreversibly. I have used staining solutions 1-2 days old, removing the pellicle with a lens paper drawn across the surface. Such an older solution should always be checked for bacteria that like the stuff. If bacteria are present, throw all out; do not filter. The growth has probably changed the $\mathrm{pH}$ of the solution. The cytologists of the Botucatu campus of UNESP prepare dilute solution for several days' use. If the solution is made aseptically and stored in a separation funnel (drained from bottom) in a cool place, it may indeed keep for some days.

Most banders filter the dilute solution before use. We had in Rio Claro one Merck solution that produced a pink dilute solution, because the blue components were retained by the No. 1 filter paper. The pink solution was useless, of course. Since I heard from Prof. S. Kasahara (17) that she is routinely using unfiltered Giemsa colutions for Vertebrata, I tried this Giemsa unfiltered, and it stained well. It seems that relatively large azure particles maintained in suspension are capable of staining. After these experiences, I do not filter the solutions any more. I use a washing bottle to remove probable precipitation from the preparation immediately when lifted from the solution.

Staining time for C-bands is usually $5-15 \mathrm{~min}$. (Webb applies his 
strong stains up to $60 \mathrm{~min}$.). Rebanding reduces the stainability of the chromosomes; in such cases I have applied the 3\% stain even overnight. Prolongation of the staining time increases the coloration to a point where staining and destaining reach an equilibrium. Placing a fully stained preparation in a stronger or weaker solution thus changes the intensity of the coloration accordingly. Prolonged staining increases the metachromasy: the bands, and finally the whole chromosomes, turn magenta.

8. Washing. Distilled water is used for washing out the excess stain: first a few squirts from a washing bottle, then 5-10 min. in distilled water, then again washing bottle, and dry. Prolonged washing in water produces decoloration. The decoloration occurs more rapidly by washing in the $\mathrm{pH} 6.9$ buffer, either strong or diluted 1:1. I dip the preparation into the buffer for a few seconds, rinse, and study it under microscope. I repeat this until a good contrast between euchromatin and bands has

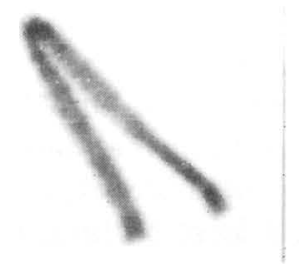

FIG. 2.-Alagoasa januaria. Unmasking " $G$ "-bands by washing in $50 \%$ buffer (Protocol 7). To the left: $Y$ chromosome after Giemsa staining; to the right: the same after 35 dips in phosphate buffer.

been formed. This method is recommended for cases where the bands are strong but euchromatin too dark (fig. 2). Magenta shades are not easily washed away.

Further factors affecting $C$-banding

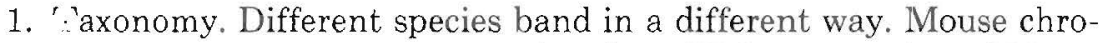
mosomes have a reputation for easy banding (Holmquist 16), and Mammalian chromosomes band generally more easily than those of invertebrates or plants. Treated together with Oedionychina, Orthopterans appeared to need somewhat milder measures, and to show less variation of results than Oedionychina. Because my material consisted almost exclusively of Oedionychina, species differences in bandability were slight.

2. Aging of the preparations was not studied. It was kept as close to one day as possible, but varied because of work pressures. Webb (43) 
"ages" the preparations keeping the slides overnight on a $55^{\circ} \mathrm{C}$ hotplate. Similar preheating of the Oedionychina chromosomes did not improve the results.

3. Distribution. Choice of the method of distribution of cells on the slides is very important for the results, and depends principally on three criteria: number of the cell divisions available, the size of the cells to be spread, and tolerance of "tortilla" (see below). Abundant metaphases allow elegant but wasteful methods; scarce mitoses need a more meticulous care.

Of the several distribution methods tried, only two serve for Oedionychina: Teasing with pins (Schedule 4), and the classical squash method (Schedule 5). The former is made on a clean (Schedule 6), the latter on an albuminized (Schedule 7) slide. All methods involving tapping or centrifugation smash the large and fragile spermatocytes, although it might be possible to develop careful centrifugation methods, using proper fixations. They would have the advantage of eliminating the "tortilla" (see below). Teasing is easier after fixation in acetic acid only, or in Carnoy's lower in alcohol than 1:3. Teasing also breaks many spermatocytes, probably because of a cutting action of the very long sperm bundles. The loss is notable: whereas there are about 40 MI cells per squashed testis in Omophoita cyanipennis F. (40), in the teasings seldom over 10 MIs are harvested. "Tortilla" is the drawback of this method. To diminish its thickness, it is best to tease on a large surface. Smith's squash was found adequate; its only drawback is the adhesive that may suffer in bandings repeated many times. For very small testes having just a few metaphases it is best to fix them in Kahle-Smith, disrupt the tissue into $2-3$ pieces in a drop of $45 \%$ acetic acid on an albuminized slide, and cover without squashing. Observation under phase contrast helps to localize the few metaphases and to squash them stepwise (Schedule 5A).

4. "Tortilla" and other sources of mosaicism. Tapped or teased, air dried preparations benefit and suffer from the water soluble proteins (principally haemolymph?) diluted in the intermedium. These preparations benefit because the drying proteins bind the cells firmly on the surface of the slide, and suffer because the same proteins hinder the action of the banding agents and stains. The negative effect increases to a real problem where the proteinic "tortilla" dries to a variable thickness, because of "towers", e.g., unbroken pieces of tissue, or, as in Oedionychina, because of large and abundant sperm bundles. The "orography" of such a preparation is that of a hilly landscape, the "tortilla" streamlining the otherwise abrupt height differences. Close to the towers, the tortilla is thick, farther away it is thinner. This is the principal cause of mosaicism of the banding results in Oedionychina. 
Other causes may exist:

Intrinsic mosaicism of the slide glass may produce mosaicism in $\mathrm{pH}$ and electric charge. Leaching of $\mathrm{Na}_{2} \mathrm{O}, \mathrm{CaO}$, and $\mathrm{SiO}_{2}$ from the glass may occur in mosaic patterns because of fabrication, such as the very thin transversal lines that attract dirt particles on some slides.

Biological pH mosaicism is to be expected in slides stored in humid tropics, where even so-called "precleaned" slides tend to grow white fungi. Thorough cleaning in acid solutions (Schedule 6) should eliminate this and the above type of mosaicism.

Mosaic preparation errors may be produced by sticking of $\mathrm{Ba}(\mathrm{OH})_{2}$ and $\mathrm{BaCO}_{3}$ to the preparations, especially if $2 \mathrm{XSSC}$ is used as hot saline. A HCl treatment after barium should eliminate this source of mosaicism.

Taking in account the experiences and considerations up to this point, I dare to recommend the procedure given in Schedule 8 as a safe minimum C-banding method for Oedionychina chromosomes, provided that the bander is prepared for rebanding.

\section{Rebanding}

Supposing that the $\mathrm{C}$-banding is due to selective destruction and elimination of chromosomal DNA, the optimal results for Oedionychina being obtainable after $17 \mathrm{~min}$. in $\mathrm{Ba}(\mathrm{OH})_{2}$ plus $1 \mathrm{~h}$ in hot saline, one would expect a failure of banding and of staining in general, if these times are grossly exceeded. This is not necessarily the case. One preparation was accidentally left in $\mathrm{Ba}(\mathrm{OH})_{2}$ for 37 min., resulting in darkly stained, solid chromosomes (Protocol 2). Rebanding with $6 \mathrm{~min}$. in $\mathrm{Ba}(\mathrm{OH})_{2}$ produced excellent C-bands. If the original banding had been with 43 min. in $\mathrm{Ba}(\mathrm{OH})_{2}$, the chromosomes would probably have been as solid as after $37 \mathrm{~min}$. in $\mathrm{Ba}(\mathrm{OH})_{2}$. In other words, it was the repetition that produced the bands, not the additional $6 \mathrm{~min}$. in barium hydroxide. Since the first experience, I have done first bandings with up to $100 \mathrm{~min}$. in $\mathrm{Ba}(\mathrm{OH})_{2}$, obtaining solid, albeit somewhat wispy, chromosomes. Apparently, the destruction of the DNA is a complicated process.

These experiences prompted me to test the performance of all the Giemsa stock solutions I found in the Rio Claro laboratory. Some of them had a good reputation as C-band stains (a couple of Merck and one Reagen), others were thought to be poor. The 6 different solutions were labeled by their $\mathrm{pH}$ values (not to be compared with aqueous $\mathrm{pH}$ 's). The age of the solutions could not be traced back, but the condition of the labels suggests that those of $\mathrm{pH} 5.95$ and 6.71 might be the oldest. Reagen $\mathrm{pH} 7.8$ was recent. It seems possible that the $\mathrm{pH}$ may decrease during the storage.

After having shaken well the stock solutions, samples of each were 
diluted to $3 \%$, with phosphate buffer of $\mathrm{pH} 6.88$, and used unfiltered. Five specimens of Alagoasa januaria Bech. and one of A. libentina Germ. were prepared in a similar way, except that 3 were fixed with 1:3 (methanol), the other 3 with Kahle-Smith (Protocol 3). In rebanding, no decoloration was attempted. The old color disappears in the baths. Table 2 shows the results.

The first banding was a failure, except for A. januaria 3 (1:3, teasing), which showed "bulk" bands (= match-head-like bands in autosomal bivalents). Addition of $2 / 60 / 5$ minutes developed further, although not sufficiently good bands. The second rebanding was a total failure. For it, a new $\mathrm{Ba}(\mathrm{OH})_{2}$ solution was used, but this should not have produced the failure. Staining was then continued in new staining solutions for 2400 min. (=50 h). This produced strong magenta colors (metachromasy) in the chromosomes, and $A$. januaria 3 showed beautiful, sharp magenta bands against blue euchromatin. It seems that the second banding had reduced irreversibly the rapid colorability of the chromosomes. Long staining is necessary from here on. Blue colors become easily washable, but magenta resists washing more. Up to this point, all 1:3-fixed, needleteased preparations showed a good to excellent C-banding.

Since the best bands were obtained using Giemsa Merck pH 6.71, a new solution of it was used to recolor the Kahle-Smith-fixed preparations. C-bands appeared in two preparations.

The results strongly suggest differences between species and between the fixation and between the stock solutions. A short formalin fixation slows down but does not hinder formation of $\mathrm{C}$-bands. This finding is important, because it allows the use of Smith's squashing technique, indispensable for saving scarce materials. Teasing is not superior to squashing, although it may so seem from this experiment. The most important findings are that rebanding can compensate a mediocrity of the stain, and a total failure can turn into a success through persistent rebanding.

It may still seem that all one has to do to obtain good $\mathrm{C}$-bands immediately, is to use the total treatment times as they can be summed up from the experimental data. Pure mathematics, alas, helps little here (see Protocols 4 and 5).

How such complex results can be interpreted in terms of DNA destruction and removal, I do not know. The process is not directly proportional to the time of treatment. May it be that after the hot saline, the proteins combined with the denatured DNA resist the next $\mathrm{Ba}(\mathrm{OH})_{2}$-treatment less than before, thus exposing the DNA with increasing efficiency to the extracting effects of the following hot saline? As this does not explain the capricious nature of some of the results, one suspects presence of small unknown hazards, peculiar for each banding sequence. 
TABLE 2.-C-banding including four rebandings

\begin{tabular}{|c|c|c|c|c|c|c|c|}
\hline \multirow{3}{*}{$\begin{array}{c}\text { Specimen } \\
\text { Band of Giemsa }\end{array}$} & \multirow[b]{3}{*}{$5 / 60 / 15$} & \multicolumn{6}{|c|}{$\mathrm{Ba}(04)_{2} / \mathrm{Holmq}$./Giemsa (min.) } \\
\hline & & 1. Rebanding & 2. Rebanding (2) & Recoloration (3) & 3. Rebanding (3) & 4. Rebanding (3) & \multirow{2}{*}{$\begin{array}{l}\text { Recoloration (3) } \\
\text { in Giemsa Merck } \\
\text { pH } 6.71200 \mathrm{~min}\end{array}$} \\
\hline & & $\begin{array}{c}2 / 60 / 5 \\
7 / 120 / 20 \\
\end{array}$ & $\begin{array}{c}2 / 30 / 5 \\
9 / 150 / 25 \\
\end{array}$ & $\begin{array}{c}-/-/ 2400 \\
9 / 150 / 2425 \\
\end{array}$ & $\begin{array}{c}2 / 60 / 300 \\
11 / 210 / 5425\end{array}$ & $\begin{array}{r}2 / 180 / 1500 \\
13 / 390 / 6925\end{array}$ & \\
\hline $\begin{array}{l}\text { A. januaria } 1 \\
\text { Ind. Quim. (1) } \\
\text { pH } 5.95\end{array}$ & Pink solid & $\begin{array}{l}\text { Blue indices } \\
\text { of } \mathrm{BS}\end{array}$ & No color & $\begin{array}{r}\text { Magenta } \\
\text { No BS }\end{array}$ & $\begin{array}{l}\text { No color } \\
\text { No BS (4) }\end{array}$ & $\begin{array}{l}\text { Faint blue in- } \\
\text { dices of BS } \\
\text { (4) }\end{array}$ & $\begin{array}{l}\text { Blue bulk } \\
\text { BS }\end{array}$ \\
\hline $\begin{array}{l}\text { A. januaria } 2 \\
\text { Merck (1) pH } \\
7.38\end{array}$ & $\begin{array}{l}\text { Magenta } \\
\text { solid }\end{array}$ & $\begin{array}{l}\text { Blue indices } \\
\text { of } \mathrm{BS}\end{array}$ & No color & $\begin{array}{r}\text { Magenta } \\
\text { No BS }\end{array}$ & $\begin{array}{l}\text { Blue some BS } \\
\text { (4) }\end{array}$ & $\begin{array}{l}\text { Faint blue } \\
\text { faint BS (4) }\end{array}$ & $\begin{array}{l}\text { Dark blue } \\
\text { sharp BS }\end{array}$ \\
\hline $\begin{array}{l}\text { A. januaria } 3 \\
\text { Merck (5) } \mathrm{pH} \\
7.60\end{array}$ & $\begin{array}{l}\text { Pinkish } \\
\text { blue bulk } \\
\text { BS }\end{array}$ & Blue bulk BS & No color & $\begin{array}{l}\text { Magenta } \\
\text { sharp BS }\end{array}$ & - & - & - \\
\hline $\begin{array}{l}\text { A. januaria } 4 \\
\text { Reagen } \mathrm{pH} \\
7.90\end{array}$ & Pink solid & Blue bulk BS & No color & $\begin{array}{l}\text { Wispy blue } \\
\text { poor bulk } \\
\text { BS }\end{array}$ & Magenta solid & Blue sharp & - \\
\hline $\begin{array}{l}\text { A. januaria } 6 \\
\text { Merck pH } \\
6.71\end{array}$ & $\begin{array}{l}\text { Pinkish } \\
\text { blue } \\
\text { solid }\end{array}$ & Blue solid & Pink solid & $\begin{array}{l}\text { Dark blue } \\
\text { solid }\end{array}$ & $\begin{array}{c}\text { Dark blue } \\
\text { bulk BS }\end{array}$ & $\begin{array}{c}\text { Dark magenta } \\
\text { sharp BS }\end{array}$ & - \\
\hline $\begin{array}{l}\text { A. libentina } \\
\text { Reagen } \\
\text { pH } 7.90\end{array}$ & Blue solid & Blue solid & No color & Magenta & $\begin{array}{l}\text { Wispy blue } \\
\text { (4) }\end{array}$ & $\begin{array}{l}\text { Faint blue } \\
\text { solid (4) }\end{array}$ & $\begin{array}{l}\text { Pinkish blue } \\
\text { solid }\end{array}$ \\
\hline
\end{tabular}

(1) Kahle-Smith.

(2) New $\mathrm{Ba}(\mathrm{OH})_{2}$ solution.

(3) New Staining solutions.

(4) Differentiation in Buffer $\mathrm{pH} 6.88$.

(5) Useless if filtered. 


\section{Ancillary bands}

In addition to genuine $\mathrm{C}$-bands marking constitutive heterochromatin, $\mathrm{C}$-banding produces in Oedionychina chromosomes the following 3 types of ancillary bands:

1. "G"-bands (figs. 1 to 4 )

2. Bulk bands (figs. 3B, 4C)

3. Kinetochore bands (figs. $6 \mathrm{~B}, 9: \mathrm{Y}$ )

"G"-bands correspond probably to chromomeres, as proper G-bands are supposed to do. They disappear if banding is repeated one or more times. They are especially found in the sex chromosomes (more in Y than X) of some species.

Bulk bands occur in the procentric regions of autosomal bivalents. Rebanding reduces them to sharp, genuine $\mathrm{C}$-bands.

A kinetochore band is just a dot in each chromatid. Most probably it marks the kinetochore of the electron microscopists, e.g., the RNP plate synthetized laterally from the centromere, for assemblage of the microtubules. In some large sex chromosomes, the kinetochore band is relatively long and laterally located (does not extend across the chromatid to which it belongs), but usually they are of rather similar size.

These ancillary bands have a somewhat limited use in identification of the chromosomes, because of the ephemerous character of the former two, and the nearly standard size of the kinetochore dot.

\section{Ag-BANDING}

I do not call this NOR-staining, because I am not convinced that only nuclear organizers are marked by these methods. There is evidence that also kinetochore plates, entire surface of all $(21,26,41)$ or some (10) meiotic sex chromosomes, fibrillar components of growing nucleoli (15, 41), and even the fibrillar (extranuclear) components of the nuclear sieve complexes of Oedionychina (41) reduce $\mathrm{AgNO}_{3}$ to silver. The common denominators responsible for the silver reaction in these cases as well as in the active NOR's, might be RNP and perhaps some acid proteins.

In the method of Pathak (Schedule 2), the concentration of formalin in the $50 \% \mathrm{AgNO}_{3}$ solution is critical and depends on the species. Some rodents band well with 1 drop of $3.5 \%$ formalin to $2 \mathrm{mI} \mathrm{Ag-nitrate} \mathrm{(17),}$ but 3 drops per $1 \mathrm{ml}$ works better for the cricket Eneoptera surinamensis (10), whereby the treatment must be prolonged to $3 \mathrm{~h}$.

Some hints were obtained that colchicine may retard the Ag precipitation. Thus colchicine-treated Acridid chromosomes required over $10 \mathrm{~h}$ of treatment to become marked (10).

Contrary to the complications met in C-banding, Ag-banding is simply accumulative. An insufficient marking can be improved by continuation 
of the treatment. Finally, the chromosomes turn entirely black. The slides must be washed well after the treatment; otherwise, the precipitation may continue. Kahle-Smith fixation combines well with Ag-banding.

Ag- and C-bands roughly coincide in Oedionychina autosomes: procentric heterochromatin and kinetochore plates become dark. The sex chromosomes are different: in mitoses, only the kinetochore plates are marked. In the meiotic prophase especially, the $\mathrm{Y}$ chromosome tends to be marked with very clear bands, which in some species are very numerous. This finding is very useful for the cytotaxonomy of Oedionychina, although it must be borne in mind that these bands vary according to the phase. Thus cells of the same meiotic phase must always be compared. Some of the strongest bands persist until MII (fig. 8C).

As a rule, the NORs are marked in the meiosis only until diplotene $(11,28)$. Thus the late markings on the Oedionychina spermatocytes are unusual. In the early diffuse stage, a droplet chain of nucleolar material is shed, just as in the classical case of a lost NOR (20). But such an early chain does not explain the late $\mathrm{Ag}$-bands. It seems more probable that the Ag-bands of Oedionychina mark the sites responsible for synthesis of the granular material that extrudes through nuclear pores to the cytoplasm and resembles chromatoid body or nucleolar material (42). Precipitation of silver in the fibrous structure of this material hints at the possibility of gene amplification (41).

\section{CYTOTAXONOMIC IMPLICATIONS}

\section{THE AUTOSOMES}

Despite the same formula, $10+\mathrm{X}+\mathrm{Y}$, all karyotypes illustrated here can be distinguished by the chromosomal morphology. The mitotic autosomes of Omophoita personata show, without any colchicine treatment, a marked difference of condensation between their arms, and apposition of the chromatids in the more condensed, long arm (fig. 3B). Compared to a similar appearance of beetle chromosomes after colchicine treatment (30), the autosomes of $O$. personata could be called "naturally diphasic" (comp. also with similar autosomes of $O$. cyanipennis: 40 ). Under such condensation conditions, the centromere appears median to submedian, and the large compact arm tends to be marked as a "bulk" band. Apparently, the "bulk" C-bands mark more the condensation than a special structure.

Surprisingly, the banding of these short autosomes is often better analyzable at PM and MI (fig. 4) than in the spermatogonial mitoses. "G"-type C-bands show that at least the largest "bulk" bands are composed of several chromomeres (fig. 4B), and that these more condensed arms are the ones that are always exempt of chiasmata-another 
parallelism with the diphasics of Chilocorus. Among the "G"-bands, only one or a few correspond to the genuine C-bands, which, in the autosomes, are always close to the free arm. The best marker among the $O$. personata autosomes is the largest, totally euchromatic-looking bivalent, which cannot be recognized among the spermatogonial autosomes at all (the largest autosomal pair of figure $3 \mathrm{~B}$ is most probably the second largest

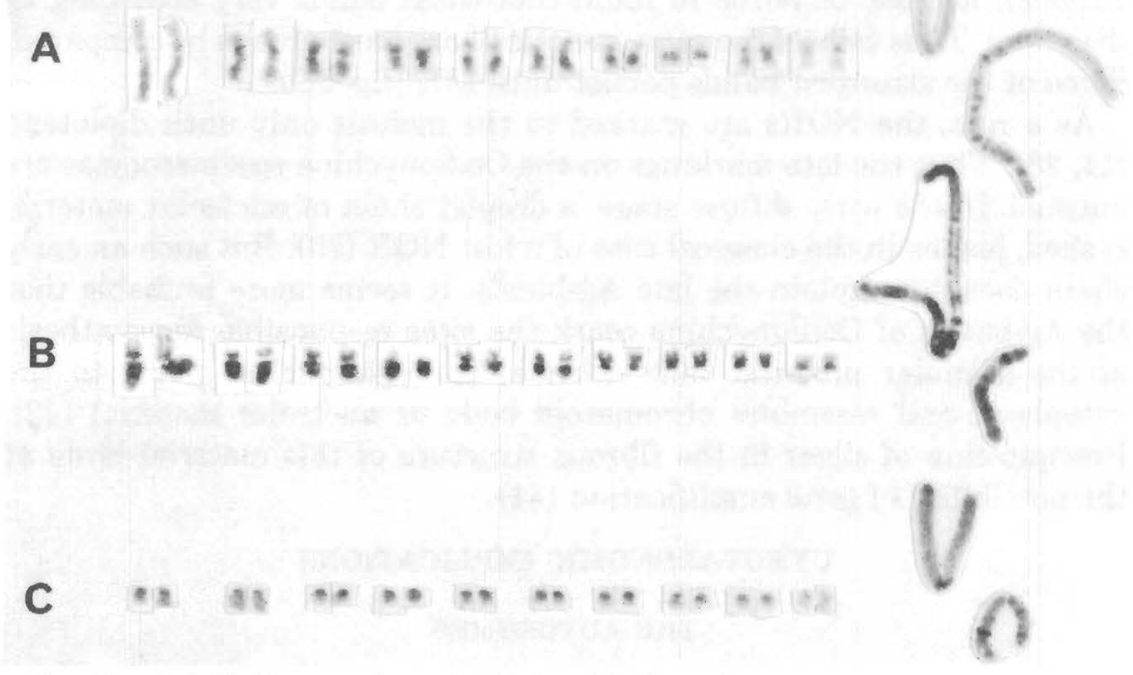

FIG. 3.-A to C, Alagoasa januaria (Protocol 8), Omophoita personata (Protocol 9), and Omophoita octoguttata (Protocol 10), respectively. - A. Very weak and diffuse bands in some autosomes, "G"-bands in the Y chromosome. This species shows morphological variation in its chromosomes (the 6 th pair in this karyogram; seen better in fig. 8A). - B. The second large arm of each autosome totally or subtotally marked. Several bands in the proximal region of $X$. The $Y$ chromosome shows " $G$ " bands, the strongest one, in the short arm, being the genuine $\mathrm{C}$-band. $-\mathrm{C}$. Weak and diffuse centromeric C-bands in the acrocentric autosomes. $\mathrm{X}$ marked procentrically. $\mathrm{Y}$ has residual "G"-banding; plus a strong $\mathrm{C}$-band in its longer arm.

of figure 4 karyograms). Like the sex chromosomes, it shows a proximal collochore at MII (fig. 5) (e.g., the last point keeping the chromatids together before anaphase is near the centromere, and not at the ends, as in the typical autosomes of Oedionychina (33 pp. 95-96). No such marker autosome occurs in the other two Omophoita spp. (figs. 3C, 6A, 7), characterized by acrocentric autosomes with very limited centromeric Cbands.

The autosomes of Alagoasa januaria (fig. 3A, 8A) show very faint 


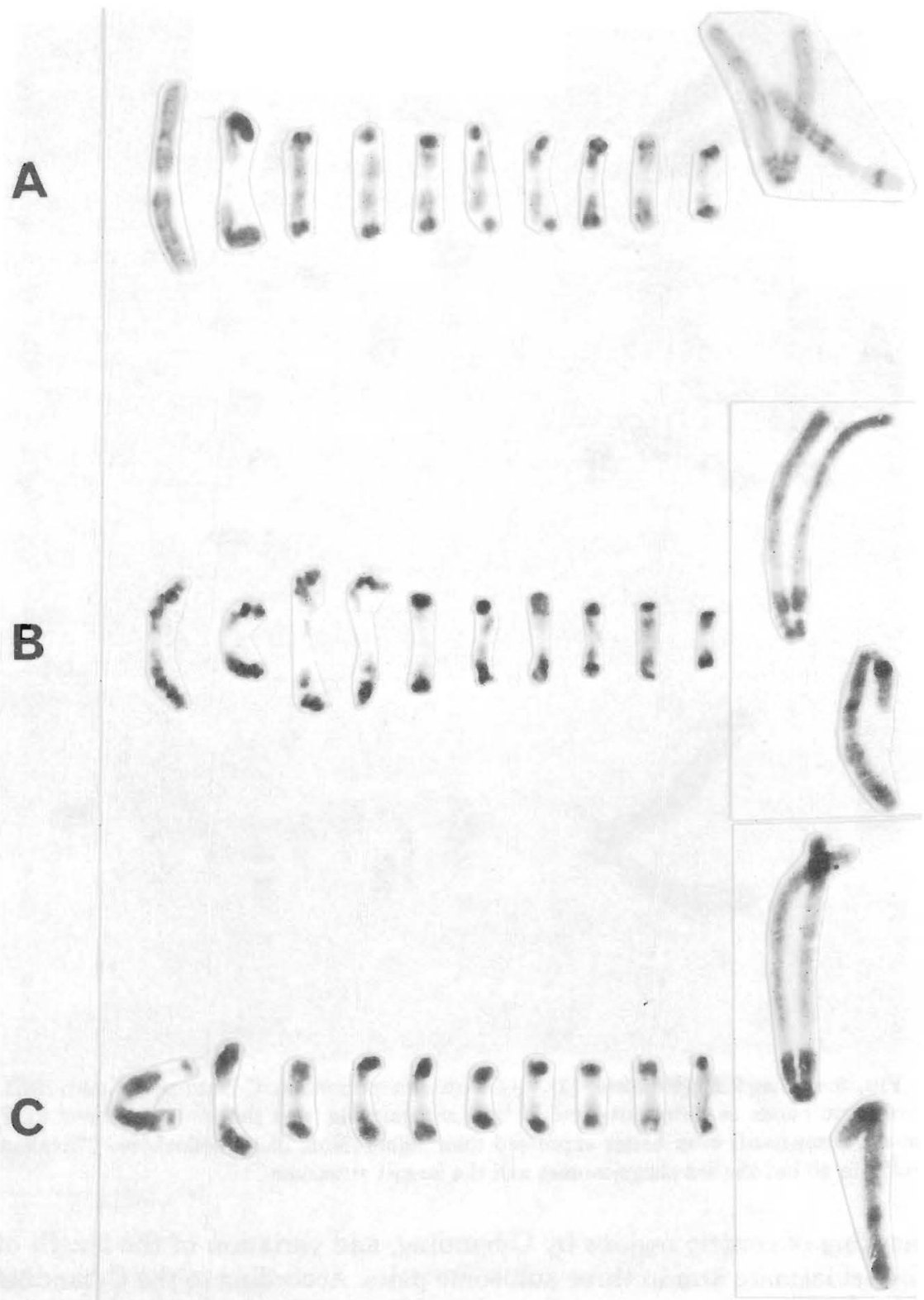

Fig. 4.-A to $\mathrm{C}$ (Protocols 9, 11, and 12, respectively). - Omophoita personata. Cbanding of male MI. - A. "Genuine" C-bands. -B. "G"-bands. - C. "Bulk" bands. The largest, acrocentric bivalent has no C-bands. The proximal regions of the $\mathrm{X}$ chromosome are symmetrically banded. The $\mathrm{Y}$ chromosome shows a strong $\mathrm{C}$-band in its short arm, and 3 bands in its long arm. 


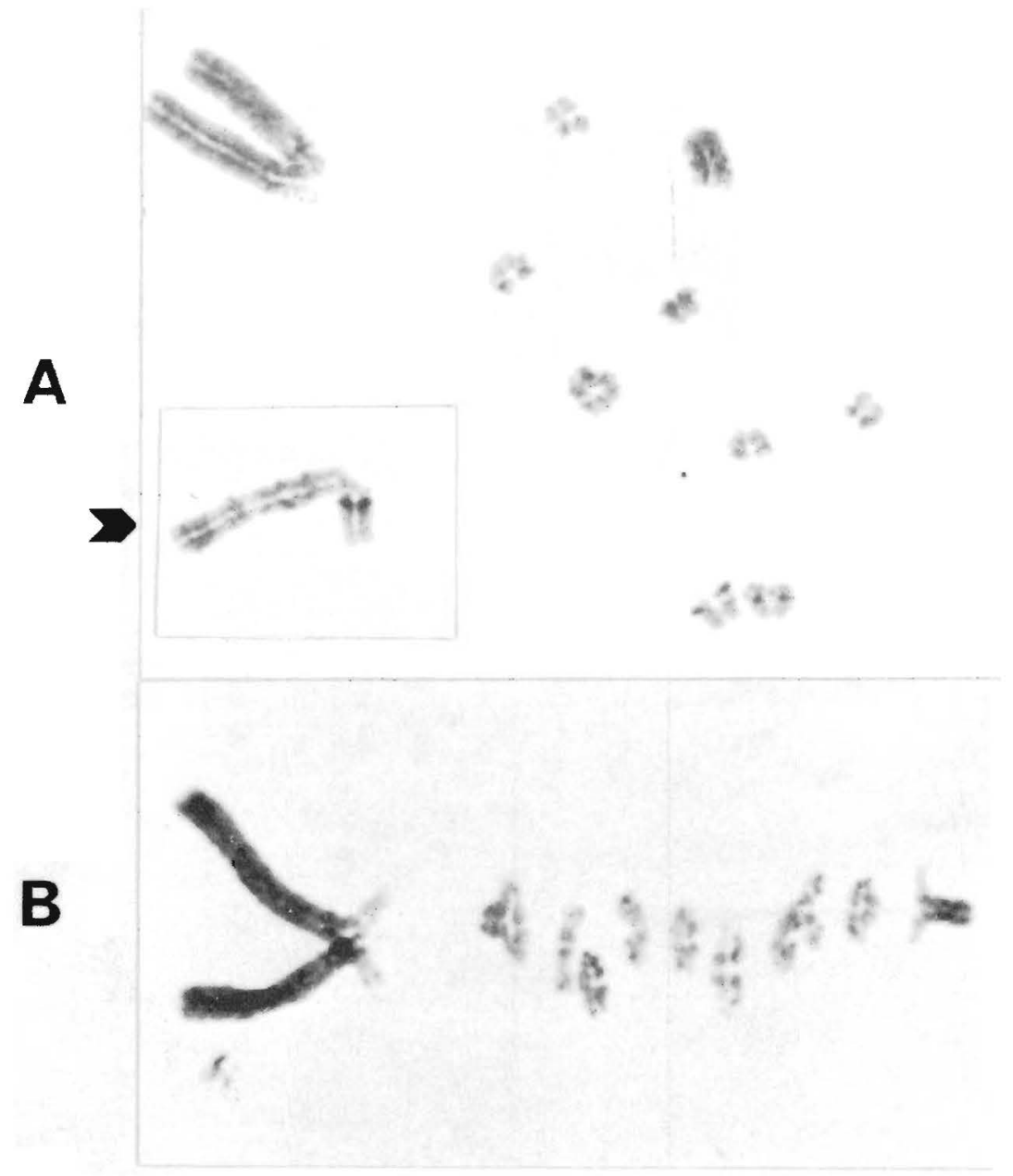

FIG. 5.-A and B (Protocol 11). -Omophoita personata. C-banding of male MII. Procentric bands in autosomes and $X$ still recognizable, and the intercalar band of $Y$ (insert, arrowhead) even better expressed than before. Note distal collochores ("bivalent look") in all but the sex chromosomes and the largest autosome.

marking of centric regions by $\mathrm{C}$-banding, and variation of the length of the achiasmate arm in three autosome pairs. According to the C-banding criterion, these arms are euchromatic. This beetle is polymorphous also externally: the number and shape of the white to violet dots on black elytra vary notably within a deme. No attempt at studying a possible correlation between the endo- and exophenotypic variation was made at this time. 
The silver marks the procentric regions of the autosomes extremely well in both Omophoita (figs. 6B, 9, 10) and Alagoasa (fig. 8B, C). Either are the markings strictly centromeric (kinetochoric?), one dot in each chromatid, as in the 8th and 10th bivalent of figure $6 \mathrm{~B}$, or-in the most cases-there are additional grains distally from the centromere. Since meiotic chromosomes beyond pachytene are not normally marked by the

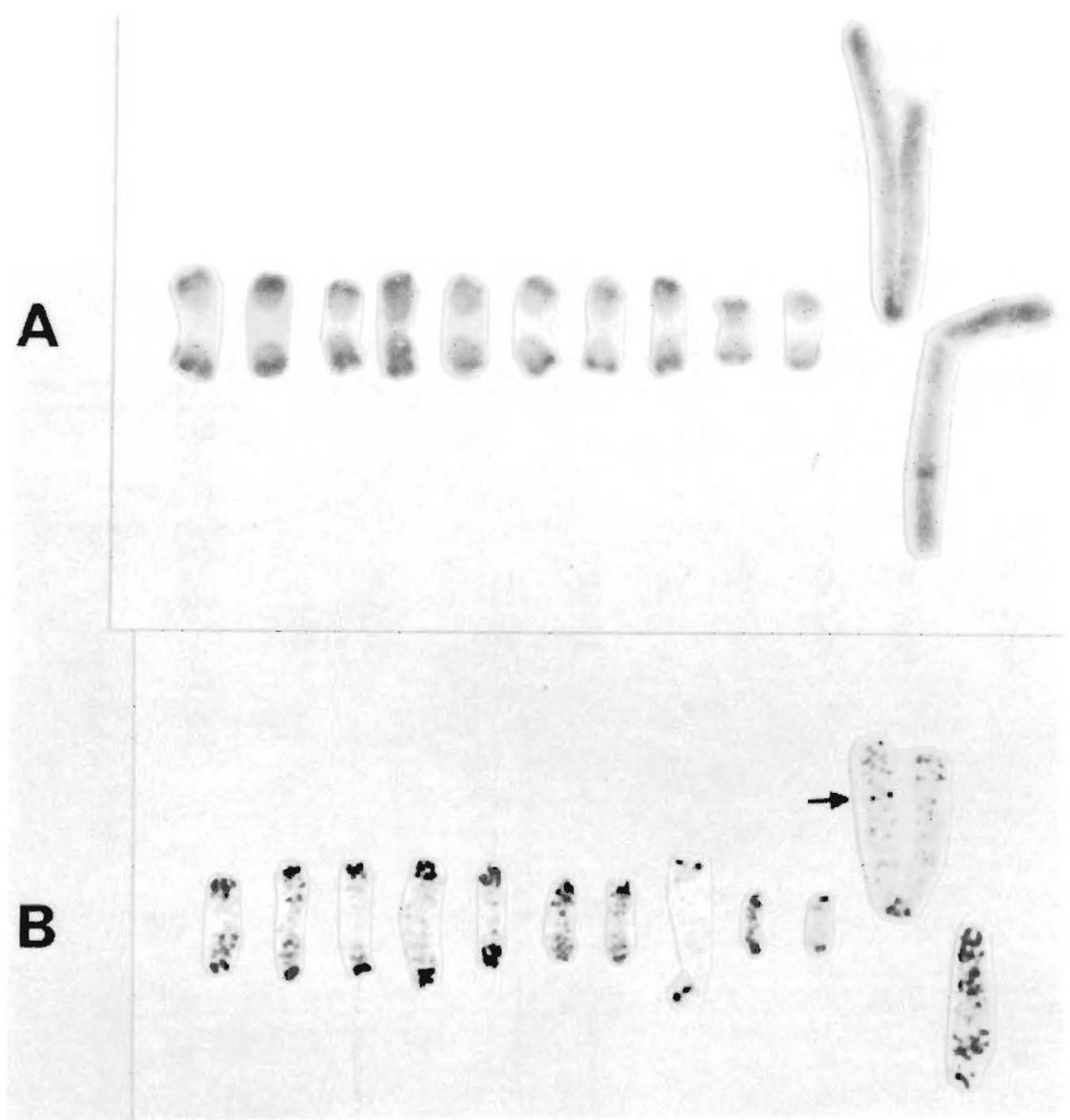

FIG. 6.-A and B (Protocols 10 and 13, respectively), -Omophoita octoguttata. C- and Ag-banding of meiotic chromosomes. - A. Centromeric C-bands in all chromosomes but $\mathrm{Y}$; the latter has one narrow band in its long arm. - B. Centromeric, procentric, and some scattered markings by $\mathrm{Ag}$ in all chromosomes. The $\mathrm{Y}$ chromosome shows a concentration of spots in one intercalar and one terminal site of its short arm, and in two intercalar and one terminal site of its long arm (seen better in fig. 10). The X shows some marking at the ends of both arms. A single dot in each of the chromatids (arrow) of its longer arm is rather constant. 
silver technique $(11,28)$, this finding is quite remarkable and has apparently to do with the synthetic activities of the long, diffuse diplotene (39, 42 ), where the procentric autosomal regions might be engaged in production of nucleoli, as even some direct observations suggest (arrowhead in figure 10) (see also 31 for organization of nucleoli at the autosomal centromeres of a non-X $\mathrm{y}_{\mathrm{p}}$ species).

\section{THE SEX CHROMOSOMES}

In karyotypes, where about a half of the total length consists of the sex chromosomes, these are expected to influence greatly the character of the karyotype.

C-banding. By this criterion, the X chromosome of all illustrated

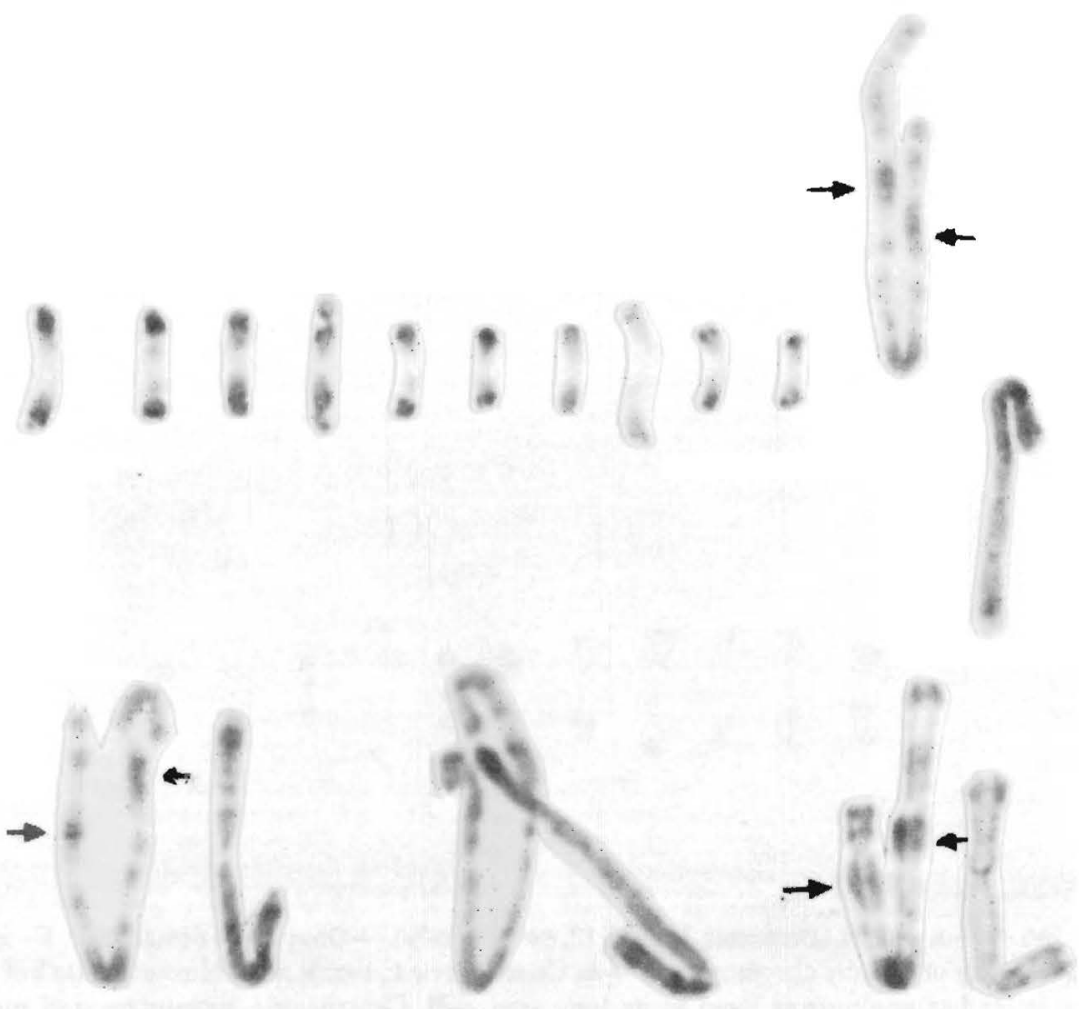

FIG. 7.-Omophoita annularis. C-banding of male meiotic chromosomes (Protocol 14). Centromeric markings in all chromosomes except for $\mathrm{Y}$; the latter has 1-2 weak bands in both arms. The X chromosome especially has a fairly constant gap pattern independent from banding (largest intercalar blocks pointed by arrows). - Lower row: The end of the longer arm of $\mathrm{X}$ tends to bend sharply, and to associate with the end of the long arm of $\mathrm{Y}$. The sex chromosome patterns are clearest at MII (to the right). 


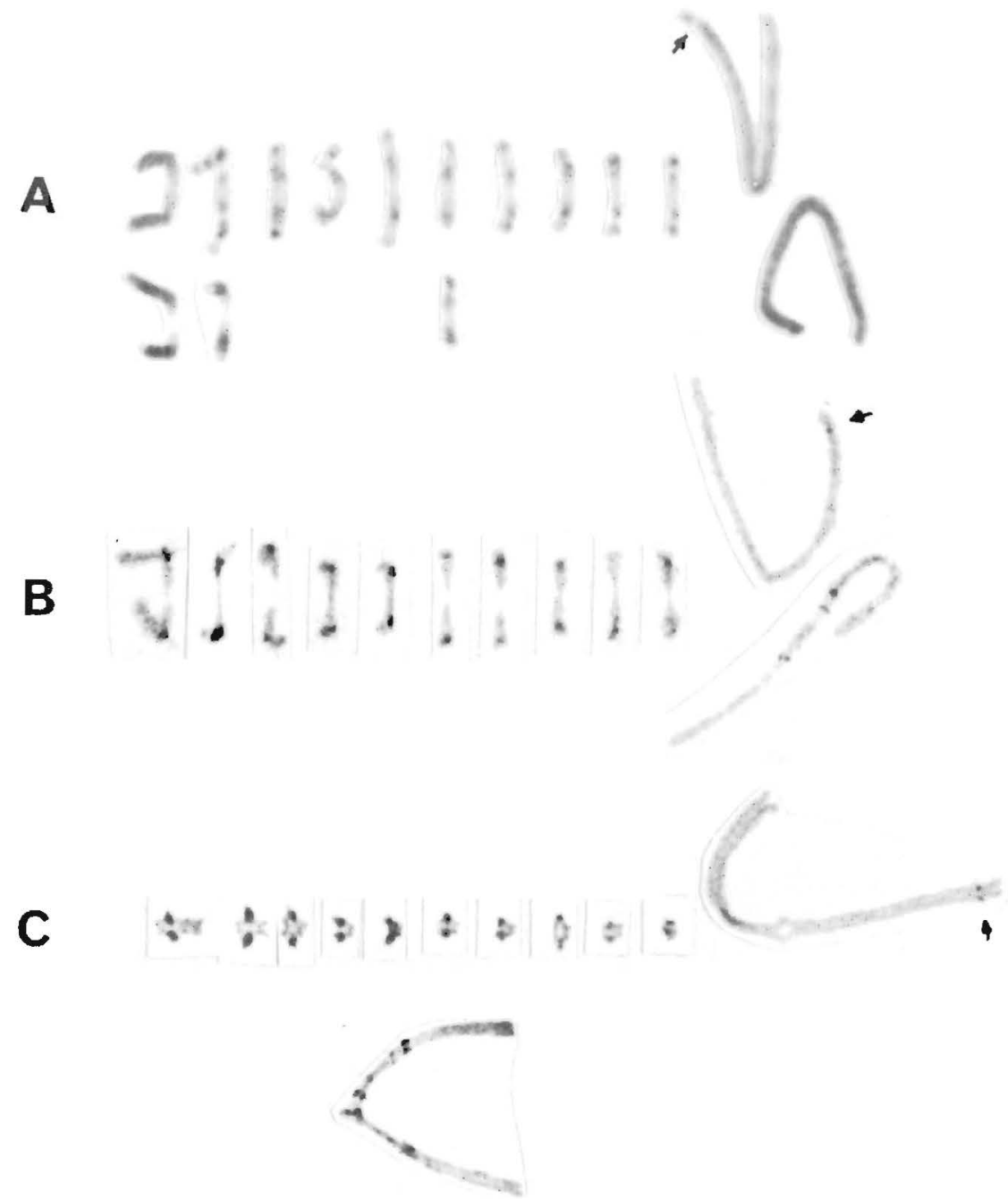

Frg. 8.-A (Protocol 15), B and C (Protocol 16). - Alagoasa januaria. C- and Ag-banding of male meiotic chromosomes. - A. MI. Very weakly marked centric regions in X and the autosomes. Morphological variation of the 1st, 2 nd, and 6 th autosome: in the full row, the 2nd and the 6th are heteromorphous bivalents; beneath, the same three bivalents from another specimen, with the 1st and the 6th bivalent heteromorphous. The $\mathrm{Y}$ chromosome has masked "G"-bands; washing with buffer, these bands could be revealed, but at the same time, the weak autosomal bands would disappear. - B. Ag-banding of MI. All centromeric regions of the autosomes marked. The $\mathrm{X}$ chromosome shows only a small spot near the end of its arms. The $\mathrm{Y}$ chromosome shows a centromeric spot, plus two double spots in the proximal half of one of its arms. - C. Ag-bands at this MII are even clearer than at MI. The $\mathrm{X}$ chromosome retains the paraterminal dot in each of the chromatids, and the $\mathrm{X}$ chromosome (below, from a different cell) shows additional dots in each of its arms. Arrows mark the paraterminal dot of $\mathrm{X}$ in $\mathrm{B}$ and $\mathrm{C}$, and the corresponding gap in $\mathrm{A}$. 
karyotypes is a largely euchromatic metacentric. The constitutive heterochromatin occurs procentrically, and very symmetrically in the form of three bands in each arm, in Omophoita personata (fig. 4), less symmetrically and in a lesser quantity in 0 . octoguttata (fig. 6A), whereas $O$. annularis and Alagoasa januaria show only a slight procentric darkening (figs. 3A, 7, 8a). The male meiotic $\mathrm{X}$ of 0 . annularis is unique in showing

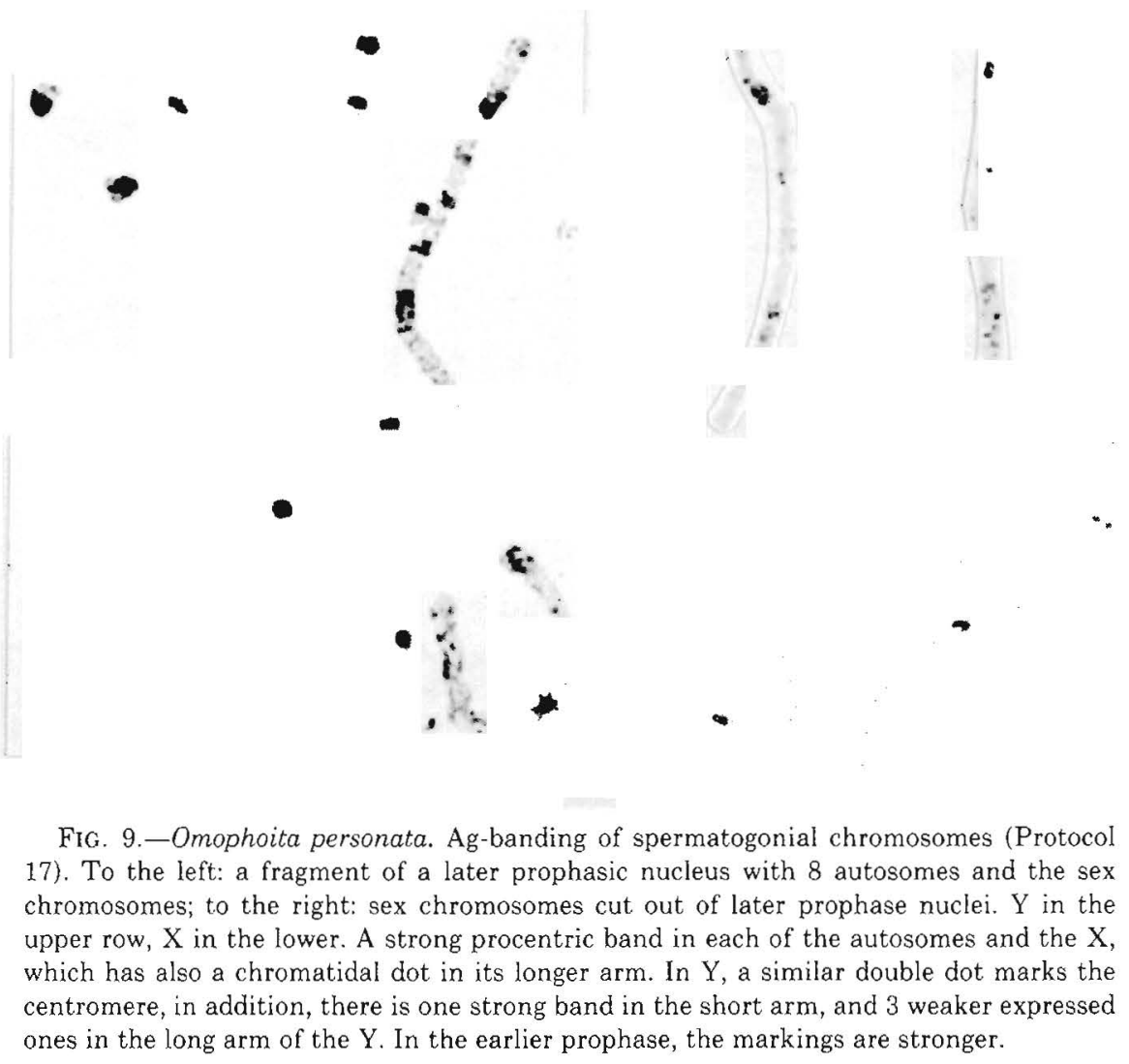

a natural gapping of relatively constant pattern. In C-banding, the pattern stains with Giemsa, but this is to be considered a "G"-banding, except perhaps, for the slightly darker procentric region, and for one intercalar bead in each arm (fig. 7). The length difference of the arms is largest in the $\mathrm{X}$ of $O$. annularis. The "extra" length of the longer arm, about 4 beads long, behaves in an exceptional way: it frequently forms a crook, the end of which shows an affinity to the long arm end of the $\mathrm{Y}$ 
chromosome (fig. 7). The same behavior of the $\mathrm{X}$ has been seen in other, unidentified Omophoita spp. (41), and might be a trend that characterizes a kinship group of species within Omophoita.

In Alagoasa januaria, the silver marks only a small dot in both chromatids of one of the arms of the nearly mediocentric $\mathrm{X}$ (figs. $8 \mathrm{~B}, \mathrm{C}$ ); this dot might be related with a gap seen in a C-banded X (fig. 8A, arrow). A similar double dot, although less distally located, occurs also in the silver

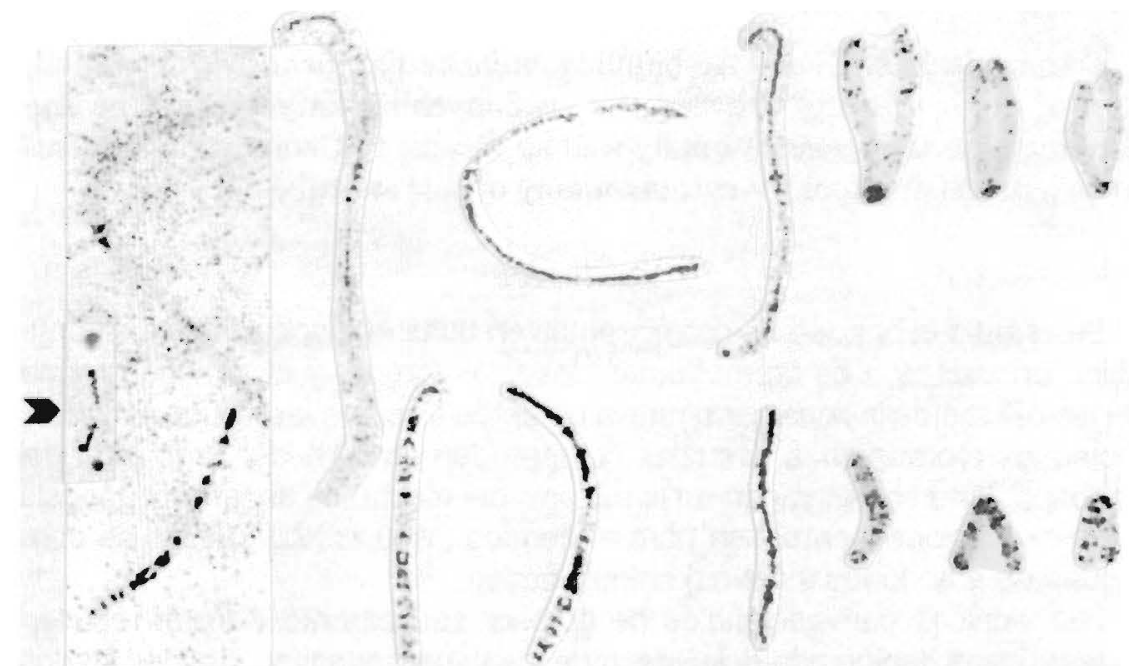

FIG. 10.-Omophoita octoguttata. Expression of the Ag-bands of the sex chromosomes from diffuse diplotene to $\mathrm{MI}$ (Protocol 13). In the X (higher row), marking of the procentric region is early and persistent. In the earlier part of the series, the shorter arm of the $\mathrm{X}$ is more heavily marked (or coiled?) than the other. Note the fairly constant double dot at the beginning of the distal third of the longer arm. The $\mathrm{Y}$ is more heavily marked (and coiled) than the X. The Ag-pattern is constant, but variably expressed due to coiling differences; up to MI, it becomes reduced to three spot groups in the long arm, two in the short arm, and one at both sides of the centromere. Insert (arrowhead): relation of two nucleoli to an autosome bivalent.

banded X of Omophoita octoguttata (figs. 6B, 10) and $O$. personata (fig. 9 ), but in these, the procentric region also becomes marked, and, in the former, to some extent, the distal thirds of both arms. Earlier, in the diffuse diplotene of $O$. octoguttata, one of the arms of $\mathrm{X}$ is marked more heavily than the other (fig. 10).

The Y chromosome is usually more heavily stained (condensed), and more inclined to show " $G$ "-banding than $\mathrm{X}$. The $\mathrm{C}$-bands are always intercalar, and different in the four illustrated species. The meiotic $\mathrm{Y}$ of Omophoita personata has one strong C-band in its short arm, and three weaker ones in the long arm (figs. 4,5). The Y of Omophoita annularis 
has one very weak C-band at the middle of its long arm, and two weak ones in its short arm (fig. 7). The Y of 0 . octoguttata is similar, with the band of the long arm more distal and the 2 bands of the short arm very diffuse (fig. 6A). The nearly mediocentric Y of Alagoasa januaria has not shown any genuine C-bands, only "G"-bands.

The silver forms a centromeric band and two intercalar ones in the proximal third of one of the arms of the Y of Alagoasa januaria (fig. 8B); these, and even some extra bands, have still been seen in the $\mathrm{Y}$ of MII (fig. 8C).

To recapitulate, $\mathrm{C}$ - and Ag-banding enhance significantly the possibilities of distinguishing between the Oedionychina karyotypes. The Agbanding especially, exceptionally well applicable to Oedionychina, seems to be a promising tool for cytotaxonomy of this subtribe.

\section{RESUMEN}

Se estudió el bandeo de cromosomas en unas 40 especies de Oedionychina brasileñas. Los cromosomas sexuales largos, y el tamaño grande de las células de la línea germinativa de estos alticinos facilita los estudios. Como los cromosomas sexuales comprenden un 50\% del largo total del cariotipo, y no se conyugan en la meiosis del macho, la espertamogénesis sirve excepcionalmente bien para el bandeo. Mitosis abundantes se consiguen de embriones (huevos) colquicinados.

Las técnicas convencionales de goipear suavemente y frotar resultan catastróficas debido a la delicadeza de los espermatocitos. Tejidos fijados en Kahle-Smith y aplastados sobre portaobjetivos son los más seguros, y buenos para la tinción argéntea, pero el fijador tiende a demorar la formación de las bandas C. Hurgar los testes con alfileres sobre el portaobjetivo conserva un $25 \%$ de las células de MI.

Las bandas $\mathrm{C}$ marcan la heterocromatina procéntrica en la mayoria de los cromosomas, y la heterocromatina intercalar, variable en tamaño y localización, en los cromosomas sexuales. El tratamiento insuficiente con $\mathrm{Ba}(\mathrm{OH})_{2}$ induce en los cromosomas sexuales (especialmente en el $\mathrm{Y}$ ), marcas parecidas a las bandas $G$. Un fracaso en el bandeo $C$ puede corregirse mediante el rebandeo, hasta 6 intentos. Una tinción prolongada en Giemsa es necesaria para los cromosomas rebandeados.

La tinción con plata marca los puntitos cinetocoriales en la mayoria de los cromosomas, así como bandas intercalares en los cromosomas sexuales del diploteno. Las más notables de estas bandas persisten hasta la MII. Los sitios activos marcados por estas bandas se relatan probablemente con la síntesis diploténica (por amplificación de genes?) de un material estructuralmente parecido a los cuerpos cromatoides.

Las diferencias de bandas entre especies muestran que las bandas C y 
Ag son instrumentos potentes para la citotaxonomía de estos coleópteros. Las bandas Ag se deben comparar con cautela, porque su número se reduce desde el diploteno a la MII.

\section{LITERATURE CITED}

1. Burkholder, G. D. and Duczeck, L. L., 1980. Proteins in chromosome banding. II Effect of $\mathrm{R}$ - and $\mathrm{C}$-banding treatment on proteins of isolated nuclei, Chromosoma 79: 4351.

2. Caspersson, T. and Zech, L., 1973. Chromosome Identification, Academic Press, New York.

3. Comings, D. E., 1978. Mechanisms of chromosome binding and implications for chromosome structure, Ann. Rev. Genet. 12: 25-46.

4. Deavan, L., 1977. In: Arrighi, F. E., Latt, S. and Miller, O., Técnicas para estudios cromosómicos. Pp. 329-43 in: Drets, M. C., Brum-Zorrilla, N. and Folle, G. A. (Ed), Joint Seminar and Workshops. Aspects of the chromosome organization and function. III. Latin American Congress of Genetics, Montevideo.

5. Tnnis, T. J., 1974a. Chromosome structure in Chilocorus (Coleoptera:Coccinellidae). I. Fluorescent and Giemsa banding patterns, Canad. J, Genet. Cytol. 16: 651-61.

6. - 1974b. Studies on heterochromatin and chromosome banding in Chilocorus (Coleoptera:Coccinellidae), Ph.D. Thesis, Dep. Zool. Univ. Toronto, Ontario, Canada.

7. - 1975. Feulgen hydrolysis and chromosome banding in Chilocorus (Coleoptera:Coccinellidae), Canad. J. Genet. Cytol. 17: 50-80.

8. - 1975. Chromosome structure in Chilocorus (Coleoptera:Coccinellidae). II. The asynchronous replication of constitutive heterochromatin, Canad. J. Genet. Cytol. 18: $85-91$.

9. - 1978. Unpublished data in Smith, S. G. and Virkiki, N.

10. Ferreira, A., Unpublished data, 1981. Instituto de Biociências, Universidade Estadual Paulista, Rio Claro, São Paulo, Brazil.

11. Forejt, J. and Goetz, P., 1979. Synaptonemal complexes of mouse and human pachytene chromosomes visualized by silver staining in air-dried preparations, Chromosoma 73: $255-61$.

12. Goodpasture, C. and Bloom, S. E., 1975. Visualization of nucleolar organizer regions in mammalian chromosomes using silver staining, Chromosoma 53: 37-50.

13. Gelfantis, S., 1963. Inhibition of cell division: a critical and experimental analysis, Int. Rev. Cytol. 14: 1-39.

14. Grouchy, J. de, Turleau, C., Roubin, M. and Colin, F. Ch., 1978. Chromosomal evolution of man and the primaies (Pan troglodytes, Gorilla gorilla, Pongo pygmaeus), pp. 124131 in: Caspersson, '1'. and Zech, L.

15. Hernández-Verdun, D., Hubert, J., Bourgeois, C. A. and Bouteille, M., 1980. Ultrastructural localization of Ag-NOR stained proteins in the nucleolus during the cell cycle and in other nucleolar structures, Chromosoma 79: 349-62.

16. Holmquist, G., 1979. The mechanism of C-banding: Depurination and $\beta$-elimination, Chromosoma 72: 203-24.

17. Kasahara, S., 1981, Unpublished data. Instituto de Biociências, Universidade Estadual Paulista, Rio Claro, São Paulo, Brazil.

18. Kimber, G., Gill, B. S., Rubenstein, J. M. and Barnhill, G. L., 1975. The technique of Giemsa staining of cereal chromosomes, Univ. Missouri-Columbia Coll. Agric. Exp. Stn Res. Bull. 1012: 3-6.

19. Lejeune, J., 1978. Scientific impact of the study of fine structure of chromatids, pp. 1624 in: Caspersson, $T$. and Zech, L. 


\section{JOURNAL OF AGRICULTURE OF UNIVERSITY OF PUERTO RICO}

20. McClintock, B., 1934. The relation of a particular chromosomal element to the development of nucleoli in Zea mays, Z. Zellf, 21: 294-328.

21. Noel, B., Quack, B. and Benezech, M., 1978. Le bivalent sexuel des Mammifères observé par marquage argentique au stade pachytène, Ann. Genet. 21: 83-7.

22. Pathak, S., 1980, Unpublished data. Dep. Biol., M.D. Anderson Hospital, Houston, Texas, U.S.A.

23. Pearson, P., 1978. The uniqueness of the human karyotype, pp. 145-151 in: Caspersson, T. and Zech, L.

24. Postiglioni, A. and Brum-Zorrilla, N., 1975. Bandas C en los cromosomas de tres especies de Stolaine Cassidines (Coleoptera: Chrysomelidae), Reun. An. SAC (Uruguay), p. 26.

25. — and — 1981. Localización de regiones organizadoras nucleolares (NORs) en otra especie con sistema sexual $\mathrm{X}_{p}$ Calligrapha polyspila (Coleoptera, Chrysomelidae, Chrysomelinae), Resum. Com. Jorn. Ci. Natur. (Uruguay), p. 32.

26. Quack, B. and Noel, B., 1977. The XY chromosome pair in mouse and human spermatocytes visualized by silver staining, Nature 267: 431-3.

27. Rees, R. W., Fox, D. P. and Naher, E. P., 1976. DNA content, reiteration and satellites in Dermestes, pp. 33-41 In: Jones, K. and Brandham, P. P. (Ed), Current Chromosome Research, North Holland, Amsterdam.

28. Schwarzacher, H. C., Mikelsaar, A. N. and Schnedl, W., 1978. The nature of the Agstaining of nucleolus organizer regions: electron and light microscopic studies on human cells in interphase, mitosis, and meiosis, Cytog. Cell Genet. 20: 24-39.

29. Smith, S. G., 1943. Techniques for the study of insect chromosomes, Canad. Entomol. 75: $21-34$.

30. - 1965. Heterochromatin, colchicine, and karyotype, Chromosoma 16: 162-5.

31. _ 1969. Nucleolar organization and chromocentre formation in Chilocorus, Chromosomes Today 2: 41-43.

32. — - 1973. Chromosomal polymorphism and interrelationships in Pissodes weevils: Additional cytogenetic evidence of synonymy, Canad. J. Genet. Cytol. 15: 83-100.

33. - and Virkki, N., 1978. Animal Cytogenetics: Coleoptera, Borntraeger, Berlin.

34. Vidal, O. R., 1980. Algunos aspectos de la meiosis en coleópteros, Acta IV Congr. Latinoam. Genética 2: 153-8.

35. - and Giacomozzi, R. O., 1978. Los cromosomas de la subfamilia Dynastinae (Coleoptera:Scarabaeidae). II. Las bandas C en Enema pan (Fabr.), Physis C 38 : $113-9$.

36. - and Virkki, N., Unpublished data, 1979.

37. Virkki, N., 1963. High chromosome number and giant postreductional sex chromosomes in the beetle Walterianella venusta Schaufuss (Chrysomelidae:Alticinae), J. Agric. Univ. P.R. 47: 154-63.

38. - 1967. Rapid allocyclic changes in the centric and an arm segment of the X chromosome of Omophoita superba Weise (Coleoptera:Alticidae), Hereditas 58: 2624.

39. - 1974. Prophase of spermatocyte I in Oedionychina (Coleoptera), J. Agric. Univ. P.R. 60: 661-74.

40. — 1979. Response of an Oedionychina (Coleoptera) karyotype to acute gamma raciation, J. Agric. Univ. P.R. 63: 116-45, 1979.

41. - 1981, Unpublished data.

42. — and Kimura, M., 1978. Distribution of nuclear pores and perinuclear dense substances in spermatocytes of some Oedionychina fleabeetles, BioSystems 10: 21325.

43. Webb, G. C., 1978. Banding methods used on grasshopper chromosomes, Roy. Children's Hosp. Melbourne, Australia, Mimeograph. 


\section{PROTOCOLS}

Protocol 1

Omophoita cyanipennis 0.6.IV.80

1. Fixation: $45 \%$ acetic acid 5 min.

2. Distribution: Teasing with needles $\rightarrow$ air dry

3. $\mathrm{HCl}: 0.2 N 25^{\circ} \mathrm{C} 15 \mathrm{~min}$.

4. $\mathrm{Ba}(\mathrm{OH})_{2}$ satur.: $30 \mathrm{sec}$.

5. Hot saline: $2 \mathrm{XSSC} 60^{\circ} \mathrm{C} 24 \mathrm{~h}$

6. Giemsa Gurr R66: $4 \%$ in $4 \%$ phosphate buffer $\mathrm{pH} 6.810 \mathrm{~min}$.

7. Washing: Aq. dest. $40 \mathrm{~min}$.

RESULT: From excellent bands to full solid color

Protocol 2

Omophoita aequinoctialis 0 28.III.81

1. Pretreatment: $4^{\circ} \mathrm{C} 20 \mathrm{~h}$

2. Hypotony: $0.075 \mathrm{M} \mathrm{KCl} 15 \mathrm{~min}$.

3. Fixation: Kahle-Smith $10 \mathrm{~min}$.

4. Distribution: Squash on albuminized slide in $60 \%$ acetic acid; glycerin in cover slip

5. Peeling-off: $50 \%$ ethanol $\rightarrow$ air dry

6. $\mathrm{Ba}(\mathrm{OH})_{2}$ conc.: made and used at $30^{\circ} \mathrm{C} 37 \mathrm{~min}$. 7.IV.81

7. $0.2 \mathrm{~N} \mathrm{HCl}: 2$ dips

8. Aq. dest.: $2 \times$

9. Hot saline: Holmquist $\mathrm{pH} 7.365^{\circ} \mathrm{C} 1 \mathrm{~h}$

10. Giemsa Merck pH 6.71: $3 \%$ in phosphate buffer $\mathrm{pH} 6.8820$ min.

11. Washing: Washing bottle--10 $\mathrm{min}$. in Aq. dest.-washing bottle

RESULT: Solid blue

12. Recoloration in the same stain overnight: Solid blue, hints of bands

13. Rebanding (6.-12.), with $6 \mathrm{~min}$. in 6., overnight in 10

RESULT: Excellent C-bands in autosomes, " $G$ "-bands in sex chromosomes

14. Differentiation: phosphate buffer $\mathrm{pH} 6.88,6$ dips

RESULT: Improved contrast

Protocol 3

13.II.81 Hypotony: $0.075 \mathrm{M} \mathrm{KCl} 1 \mathrm{~h}$

Fixation: Alagoasa januaria 1 and $2\left(\delta^{\star}\right)$; Walterianella $53 \delta^{*}$

Kahle-Smith 3 and 2 min., respectively

Alagoasa januaria 3,4 and $6\left(\delta^{\wedge}\right)$; A. libentina (ठ)

1:3 (metan.) $45 \mathrm{~min} .25^{\circ} \mathrm{C}+2 \mathrm{~h} 4^{\circ} \mathrm{C}$ 
Distribution: K-S-fixed; Squash on albuminized slide in $60 \%$ acetic acid $\rightarrow 50 \%$ ethanol $\rightarrow$ air dry; 1:3 fixed: Teasing on clean slide in $60 \%$ acetic acid $\rightarrow$ air dry

20.II.81 $\mathrm{Ba}(\mathrm{OH})_{2}$ conc.: $30^{\circ} \mathrm{C}$ (the time varied)

$\mathrm{HCl} 0.1 \mathrm{~N}: 3$ dips

Aq. dest.: $2 \times \rightarrow$ air dry

Holmquist: $\mathrm{pH} 7.365^{\circ} \mathrm{C}$ (the time varied)

Giemsa 3\% (Merck): (the time varied)

Washing: bottle -10 min.--bottle

RESULT: Solid to bulk bands

Proctocol 4

27.II.81 Material: Alagoasa fasciaticollis 45 ㅇ; Alagoasa 35 우 and o

$\mathrm{Ba}(\mathrm{OH})_{2}$ conc.: $30^{\circ} \mathrm{C} 20 \mathrm{~min}$.

HCl $0.1 \mathrm{~N}: 3$ dips

Aq. dest.: $2 \times \rightarrow$ air dry

Holmquist: $\mathrm{pH} 7.365^{\circ} \mathrm{C} 61 / 2 \mathrm{~h}$

Giemsa (Merck): $\mathrm{pH} 7.65 \mathrm{~min}$.

Washing: bottle-10 min. - bottle

RESULT: Blue, solid

Protocol 5

27.II.81 Material: Alagoasa 35 ; Alagoasa 56 q

$\mathrm{Ba}(\mathrm{OH})_{2}$ conc.: $30^{\circ} \mathrm{C} 9$ min.

$\mathrm{HCl} 0.1 \mathrm{~N}: 2$ dips

Aq. dest.: $2 \times$

Holmquist: $\mathrm{pH} 7.365^{\circ} \mathrm{C} 21 / 2 \mathrm{~h}$

Giemsa (Merck): pH 7.65 min.

Washing: bottle-10 min.-bottle

RESULT: Pinkish blue, solid, except for kinetochore dots in some chromosomes

Protocol 6

6.III.81 Material: Omophoita octoguttata (Fig. 1)

Hypotony: $0.075 \mathrm{KCl} 1 \mathrm{~h}$

Fixation: Kahle-Smith $31 / 2$ min.

Distribution: Smith's squash $\rightarrow 50 \%$ ethanol $\rightarrow$ air dry $\mathrm{Ba}(\mathrm{OH})_{2}$ satur.: $30^{\circ} \mathrm{C} 9 \mathrm{~min}$

$0.1-N$ HCl: 2 sec. $\rightarrow$ Aq. dest. $2 \times 5$ min.

Holmquist's buffer $\mathrm{pH} 7.3: 65^{\circ} \mathrm{C} 2 \mathrm{~h}$

Giemsa Merck "pH 6.71": $4 \%$ in full phosphate buffer pH 6.705 min.

Washing: bottle +10 min. + bottle $\rightarrow$ air dry 
Protocol 7

2.X.80 Material: Alagoasa januaria (Fig. 2)

Hypotony: $0.075 \mathrm{M} \mathrm{KCl} 20 \mathrm{~min}$.

Fixation: 1:1 (ethanol 96\%) $1 \mathrm{~h}$, plus $4 \mathrm{~h}$ at $4^{\circ} \mathrm{C}$

Distribution: pins, $60 \%$ acetic acid $\rightarrow$ air dry, left for two days

Refixation: 1:3 (ethanol $2 \times 15 \mathrm{~min}$, air drying in between $\rightarrow$ air dry

$\mathrm{Ba}(\mathrm{OH})_{2}$ satur.: $30^{\circ} \mathrm{C} 8 \mathrm{~min}$.

$0.1 \mathrm{~N} \mathrm{HCl}: 3 \mathrm{sec}, \rightarrow$ aq. dest. $-30 \%-50 \%-70 \%-95 \%-$ $100 \%$ ethanol $\rightarrow$ air dry

Holmquist's buffer $\mathrm{pH}$ 7.3: $60^{\circ} \mathrm{C}, 2 \mathrm{~h}$

Giemsa VEAFARM: $4 \%$ in full phosphate buffer $\mathrm{pH}$ $6.88,15 \mathrm{~min}$.

Washing: bottle -10 min. - bottle

Differentiation: 35 dips in phosphate buffer $\mathrm{pH} 6.88$ diluted to $50 \%$

Washing: bottle $-10 \mathrm{~min} .-$ bottle $\rightarrow$ air dry

Protocol 8

9.III.81 Material: Alagoasa januaria (Fig. 3A)

Hypotony: $0.075 \mathrm{M} \mathrm{KCl} 20 \mathrm{~min}$.

Fixation: glycerine 1:glacial acetic acid 1:aq. dest. 12 h 45 min.

Distribution: pins, $60 \%$ acetic acid $\rightarrow$ air dry, left for $24 \mathrm{~h}$

$\mathrm{Ba}(\mathrm{OH})_{2}$ satur.: $30^{\circ} \mathrm{C} 8 \mathrm{~min}$.

$0.1 \mathrm{~N} \mathrm{HCl}: 3 \mathrm{sec} . \rightarrow$ aq. dest. (accumulating all slides) $30 \%-50 \%-70 \%-95 \%-100 \%$ ethanol $\rightarrow$ air dry

Holmquist's buffer pH 7.3: $65^{\circ} \mathrm{C} 1 \mathrm{~h}$

Giemsa VEAFARM: $4 \%$ in full phosphate buffer $\mathrm{pH}$ $6.8815 \mathrm{~min}$.

Washing: Aq. dest. bottle $-10 \mathrm{~min} .-$ bottle $\rightarrow$ air dry

Protocol 9

9.IX.80 Material: Omophoita personata (Figs. 3B, 4B)

Fixation: 1:2 (ethanol) $4 \mathrm{~h}$

Distribution: pins, $45 \%$ acetic acid $\rightarrow$ air dry

Refixation: 1:2 (ethanol) $2 \times 30 \mathrm{~min}$., air drying in between $\rightarrow$ air dry; left dry for two days

$\mathrm{Ba}(\mathrm{OH})_{2}$ satur.: $30^{\circ} \mathrm{C} 7 \mathrm{~min}$.

$0.1 \mathrm{~N} \mathrm{HCl}: 3 \mathrm{sec} . \rightarrow$ aq. dest. (accumulating all slides)30\%- 50\%- 70\%- 95\%- 100\% ethanol $\rightarrow$ air dry

Holmquist's buffer $\mathrm{pH} 7.3: 65^{\circ} \mathrm{C} 1 \mathrm{~h}$ 
Rinse: in phosphate buffer $\mathrm{pH} 7.00$

Giemsa: $8 \% 6$ min.

Washing: bottle $-10 \mathrm{~min}$. - bottle $\rightarrow$ air dry

Protocol 10

15.IX.80 Material: Omophoita octoguttata (Figs. 3C, 6A)

Hypotony: $0.075 \mathrm{M} \mathrm{KCl} 15 \mathrm{~min}$.

Fixation: 1:1 (ethanol) 3 h 40 min., two changes

Distribution: pins, $60 \%$ acetic acid $\rightarrow$ air dry, left for $48 \mathrm{~h}$

Refixation: 1:3 (ethanol) $2 \times 30$ min., dried and left dry in between for $30 \mathrm{~min} . \rightarrow$ air dry

$\mathrm{Ba}(\mathrm{OH})_{2}$ satur.: $30^{\circ} \mathrm{C} 9$ min.

$0.1 \mathrm{~N} \mathrm{HCl}: 2 \mathrm{sec} . \rightarrow$ aq. dest. $2 \times 5 \mathrm{~min}$. $\rightarrow$ air dry, left for $11 / 2 \mathrm{~h}$

Holmquist's buffer pH 7.3: $65^{\circ} \mathrm{C} 1 \mathrm{~h}$

Giemsa VEAFARM: $4 \%$ made in $6 \mathrm{ml}$ phosphate buffer pH 6.88 plus $50 \mathrm{ml}$ aq. dest.; $1 \mathrm{~h}$

Washing: bottle $+1 \mathrm{hr}+$ bottle $\rightarrow$ air dry

Protocol 11

15.IX.80 Material: Omophoita personata (Figs. 4A, 5)

Hypotony: $0.075 \mathrm{M} \mathrm{KCl} 12 \mathrm{~min}$.

Fixation: 1:1 (ethanol) 3 h 20 min., 1 change

Distribution: pins, $60 \%$ acetic acid $\rightarrow$ air dry, left for 2 days

Refixation: 1:3 (ethanol) $2 \times 30 \mathrm{~min}$., dried in between and left dry for $30 \mathrm{~min} . \rightarrow$ air dry

$\mathrm{Ba}(\mathrm{OH})_{2}$ satur.: $30^{\circ} \mathrm{C} 21 \mathrm{~min}$.

$0.1 \mathrm{~N} \mathrm{HCl}: 2 \mathrm{sec} . \rightarrow$ aq. dest. $-30 \%-50 \%-70 \%-98 \%-$ $100 \%$ ethanol $\rightarrow$ air dry

Holmquist's buffer pH 7.3: $65^{\circ} \mathrm{C} 1 \mathrm{~h}$

Rinse: in phosphate buffer $\mathrm{pH} 6.88$

Giemsa VEAFARM: $4 \%$ in $6 \mathrm{ml}$ phosphate buffer $\mathrm{pH}$ 6.88 plus $50 \mathrm{ml}$ aq. dest. $1 \mathrm{~h}$

Washing: bottle $-1 \mathrm{~h}-$ bottle $\rightarrow$ air dry

Protocol 12

15.X.80 Material: Omophoita personata (Fig. 4C)

Hypotony: $0.075 \mathrm{M} \mathrm{KCl} 15 \mathrm{~min}$.

Fixation: 1:1 (ethanol 95\%) $1 \mathrm{hr}+2 \mathrm{~h}$ at $4^{\circ} \mathrm{C}$

Distribution: pins, $60 \%$ acetic acid $\rightarrow$ air dry, left for 5 days

$\mathrm{Ba}(\mathrm{OH})_{2}$ satur.: $30^{\circ} \mathrm{C} 7 \mathrm{~min}$.

$0.1 \mathrm{~N} \mathrm{HCl}: 3 \mathrm{sec}$ - aq. dest.-30\%- 50\%- 70\%- 95\%$100 \%$ ethanol $\rightarrow$ air dry 
Holmquist's buffer $\mathrm{pH} 7.3: 65^{\circ} \mathrm{C} 2 \mathrm{~h}$

Giemsa VEAFARM: $3 \%$ in full phosphate buffer $\mathrm{pH}$ $6.88,15 \mathrm{~min}$.

Washing: bottle $-10 \mathrm{~min}$. - bottle $\rightarrow$ air dry

Protocol 13

28.III.81 Material: Omophoita octoguttata (Figs. 6B, 10)

Hypotony: $0.075 \mathrm{M} \mathrm{KCl:} 5 \mathrm{~min}$.

Fixation: Kahle-Smith 3 1/2 min.

Distribution: Smith's squash in $60 \%$ acetic acid $\rightarrow 50 \%$ ethanol $\rightarrow$ air dry, left for 10 days

Protocol 14

Ag-banding: Schedule 2, with $60 \mathrm{~min}$. in $\mathrm{AgNO}_{3}$

24.IX.80 Material: Omophoita annularis (Fig. 7)

Hypotony: $0.075 \mathrm{M} \mathrm{KCl} 15 \mathrm{~min}$.

Fixation: 1:1 (ethanol) $1 \mathrm{~h},+3 \mathrm{~h}$ at $4^{\circ} \mathrm{C}$

Distribution: pins, $60 \%$ acetic acid $\rightarrow$ air dry, left for $24 \mathrm{~h}$

Refixation: 1:3 (ethanol 95\%) $2 \times 30$ min., air dried for $14 \mathrm{~h}$. in between $\rightarrow$ air dry, left for two days

$\mathrm{Ba}(\mathrm{OH})_{2}$ satur.: $30^{\circ} \mathrm{C} 8$ min.

$0.1 \mathrm{~N} \mathrm{HCl}: 1 \mathrm{~min}$-aq. dest. (accumulating all slides)-30\%-50\%-70\%-96\%-100\% ethanol $\rightarrow$ air dry

Holmquist's buffer $\mathrm{pH} 7.3: 65^{\circ} \mathrm{C} 1 \mathrm{~h}$

Rinse: phosphate buffer $\mathrm{pH} 6.88$

Giemsa VEAFARM: $4 \%$ in $6 \mathrm{ml}$. phosphate buffer $\mathrm{pH}$ 6.88 plus $50 \mathrm{ml}$ aq. dest., $30 \mathrm{~min}$.

Washing: bottle-10 min.-bottle $\rightarrow$ air dry

Protocol 15

24.IX.80 Material: Alagoasa januaria (Fig. 8A)

Hypotony: $0.075 \mathrm{M} \mathrm{KCl} 17 \mathrm{~min}$.

Fixation: 1 : (ethanol) $1 \mathrm{~h}+4 \mathrm{~h}$ at $4^{\circ} \mathrm{C}$

Distribution: pins, $60 \%$ acetic acid $\rightarrow$ air dry

Refixation: 1:3 (ethanol 95\%) $2 \times 30$ min., dried in air in between and left for overnight $\rightarrow$ air dry, left for two days

$\mathrm{Ba}(\mathrm{OH})_{2}$ satur.: $30^{\circ} \mathrm{C} 8 \mathrm{~min}$.

$0.1 \mathrm{~N} \mathrm{HCl}: 4 \mathrm{~min} \rightarrow$ aq. dest. (accumulating all slides) $30 \%-50 \%-70 \%-96 \%-100 \%$ ethanol $\rightarrow$ air dry, left for $1 \mathrm{~h}$

Holmquist's buffer $\mathrm{pH}$ 7.3: $65^{\circ} \mathrm{C} 1 \mathrm{~h}$

Rinse: phosphate buffer pH 6.88

Giemsa VEAFARM: $4 \%$ in $6 \mathrm{ml}$. phosphate buffer $\mathrm{pH}$ 6.88 plus $50 \mathrm{mI}$ aq. dest., $30 \mathrm{~min}$. 
Protocol 16

Washing: bottle $-10 \mathrm{~min}$. - bottle $\rightarrow$ air dry

24.I.81 Material: Alagoasa januaria (Figs. 8B and C)

Hypotony: $0.075 \mathrm{M} \mathrm{KCl} 2 \mathrm{~h} 30 \mathrm{~min}$.

Fixation: Kahle-Smith 4 min.

Distribution: Smith's squash in $60 \%$ acetic acid $\rightarrow 50 \%$ ethanol $\rightarrow$ air dry

$\mathrm{Ag}$-banding: $50 \% \mathrm{AgNO}_{3}$ at $50^{\circ} \mathrm{C}$ for $3 \mathrm{~h}$, plus $50 \mathrm{~h}$ at about $20^{\circ} \mathrm{C}$

Protocol 17

Rinse: aq. dest. $3 \times 10$ min. $\rightarrow$ air dry

9.III.81 Material: Omophoita personata (Fig. 9)

Hypotony: $0.075 \mathrm{M} \mathrm{KCl} 15 \mathrm{~min}$.

Fixation: 1:3 (methanol) $1 \mathrm{~h}$

Distribution: Squash on albuminized slide $\rightarrow 50 \%$ ethanol $\rightarrow$ air dry

Ag-banding: Schedule 2, vith $30 \mathrm{~min}$. in $\mathrm{AgNO}_{3}$

\section{SCHEDULES}

Schedule 1

C-banding according to Vidal \& Giacomozzi (35)

1. Preparations fixed in acetic ethanol and air dried.

2. Ethanol $95 \% 2 \times 2 \mathrm{sec}$.

3. $\mathrm{NaCl} 0.9 \%$, submerging slowly, $8 \times$.

4. $\mathrm{Ba}(\mathrm{OH})_{2}$ satur. $12-18 \mathrm{~min}$. at room temperature.

5. Ethanol $70 \% 3 \times 2 \mathrm{sec}$.

6. $\mathrm{NaCl} 0.9 \% 3 \times 2 \mathrm{sec}$.

7. $2 \mathrm{XSSC}$, incubation for $2 \mathrm{~h}$ at $60^{\circ} \mathrm{C}$.

8. Rinse in aq. dest.

9. Air dry.

10. Giemsa 2 parts: phosphate buffer $\mathrm{pH} 6.82$ parts; aq. dest. 96 parts.

11. Rinse in aq. dest. $3-4 \times$.

12. Air dry.

Schedule 2

S. Pathak's silver staining (22)

1. Air dried preparations of any age.

2. Borate buffer ${ }^{\mathrm{x}} \mathrm{pH}$ 9.0-9.1 for 15-30 min.

3. Aq. dest. $2 x$

4. Form drops of $3.5 \%$ formalin with needle no. 27 (tuberculine syringe) and mix with $2 \mathrm{ml}$ of $50 \% \mathrm{AgNO}_{3}$. The strength of the mixture depends on species. $2 \mathrm{gtt} / 2 \mathrm{ml}$ is usually good for Oedionychina. 
5. Place drops of the mixture on the preparation and cover with coverslip.

6. Keep in $100 \%$ humidity (petri dish) at $65^{\circ} \mathrm{C}$ for about $1 \mathrm{~h}$.

7. Keep in Aq. dest. $3 \times, 10$ min. each.

8. $4 \%$ Giemsa, if needed, for euchromatin.

9. Washing bottle-10 min. in A. dest.-washing bottle.

10. Study uncovered. If silver reaction incomplete, repeat. ${ }^{x}$ Borate buffer: $0.1 \mathrm{M}(14.20 \mathrm{~g}) \mathrm{Na}_{2} \mathrm{SO}_{4} \quad$ )

Schedule 3

$$
\left.0.005 \mathrm{M}(1.91 \mathrm{~g}) \mathrm{Na}_{2} \mathrm{~B}_{4} \mathrm{O}_{7}\right) \text { in } 1 \text { 1. Aq. }
$$

Colchicine treatment for arresting mitoses and for Smith's colchicine test

A. Adults (usually females)

Using a tuberculine syringe of $1 \mathrm{ml}$, provided with a no. 27 needle, inject $0.01 \%$ colchicine in Ringer to the abdomen, until it starts swelling. The injection of small specimens is very difficult without a micrometer pusher, such as the micrometer syringe outfit of Burroughs, Wellcome \& Co. (London). Wait $2+\mathrm{h}$ for arrested mitoses. For Smith's test, wait about 17-18 h (Oedionychina).

Result: "cryptic" heterochromatin less condensed than euchromatin.

B. Embryos

Remove both ends of an egg 14 days old (Oedionychina), and submerge in $0.01 \%$ colchicine made in Ringer, and wait as above.

Schedule 4

Distribution by needles (Oedionychina only)

1. Fix in Carnoy 1:3, in Carnoys lower in alcohol, or in $45 \%$ acetic acid.

2. Bring testis on a clean slide in a drop of $45 \%$ acetic acid $(60 \%$, if fixed in full Carnoy), and tease with needles or insect pins. Eliminate somatic tissues. Cover a large area, to minimize "tortilla" effects.

3. Dry in air in horizontal position.

Schedule 5

Squash, modified from Smith (29)

1. Fix in Carnoy 1:3 for about $1 \mathrm{~h}$ (one change), or in Kahle-Smith for 1-4. min., according to experience. Kahle-Smith (1 part glacial acetic acid: 3 parts Formalin: 7.5 parts $95 \%$ ethanol) is better, but may not work well with all bandings.

2. Bring the gonad on an albuminized slide in a drop of $45 \%$ or $60 \%$ 
acetic acid, tease to several pieces with watchmaker's forceps, eliminate somatic tissues, and distribute on an area slightly less than the coverslip to be used. Ovarial germaria are distributed entire.

3. Cover and study unsquashed in phase contrast. If only a few divisions present, proceed via $\mathrm{A}$, if divisions abundant, go directly to $\mathrm{B}$.

A. Select a good cell, cover with hard paper, and gently squash the site with a flat (unworn) rubber-end of a pencil. Check in phase contrast and repeat the operation until satisfactory results obtained. Pass to $\mathrm{B}$.

B. Gently warm the slide above alcohol flame, cover with a piece of hard paper, and squash with thumb. The smaller the cells, and the longer the fixation with Kahle-Smith, the stronger the squashing pressure must be.

4. Study and photograph in phase contrast. Add acetic acid if the preparation begins to dry.

5. Peel-off the coverslip in 50\% ethanol. Clean squashes drop their coverslips off in 5-10 min. Some must be helped with a razor blade. If step no. 4 is avoided, then it is recommendable to smear a thin layer of glycerine on the coverslip before squashing.

6. Dry in air.

Schedule 6

Cleaning of slides: either A or B

A. 1. Sonification in filtered tap water with the accustomed soap or detergent.

2. Rinse in filtered tap water.

3. Bring to boil in $0.2 \mathrm{~N} \mathrm{HCl}$ made in Aq. dest.

4. Rinse in Aq. dest. $2 \times$.

5. Store in filtered $95 \%$ ethanol.

Pass through $100 \%$ alcohol for drying and use.

B. Webb's (39) method

1. Clean in the following solution (avoid spontaneous overheating when preparing it!):

$60 \mathrm{~g} \mathrm{~K}_{2} \mathrm{Cr}_{2} \mathrm{O}_{7}$

$500 \mathrm{ml}$ filtered tap water

$1500 \mathrm{ml} \mathrm{H}_{2} \mathrm{SO}_{4}$ conc.

2. Rinse in running filtered tap water.

3. Rinse in Aq. dest. $2 \times$.

4. Store in filtered $95 \%$ ethanol.

Pass through $100 \%$ ethanol for drying and use.

Obs. (A and B): Sharp edges of the slides harvest dead epithelial cells 
from the fingers. To avoid this contamination, use

Schedule 7 forceps or gloves, and ground-edged slides.

Albuminization of slides

A. Albumen

1. Punch a small hole in both ends of a fresh egg.

2. Blow from one end until a clear drop of albumen about $0.5-1$ $\mathrm{ml}$ forms at the opposite end.

3. Cut the drop with scissors and let fall into a small graduated cylinder.

4. Add equal quantity of glycerine and mix well.

5. Store in refrigerator at $4^{\circ} \mathrm{C}$ for a maximum of 1 month.

B. Albuminization

1. Spread a small amount of the mixture on a clean slide, using a clean finger and a few unidirectional strokes.

2. With a lintless paper and unidirectional strokes, remove the excess until a very thin layer of the mixture remains on the slide.

3. Heat over alcohol flame until the mixture dries (glycerine evaporates). Use within a couple of days.

Schedule 8

Minimum C-banding for Oedionychina

1. An air dried preparation made the day before.

2. $\mathrm{Ba}(\mathrm{OH})_{2}$ saturated and kept at $30^{\circ} \mathrm{C}, 7 \mathrm{~min}$.

3. $0.2 \mathrm{~N} \mathrm{HCl} 2$ dips.

4. Aq. dest $2 \times$.

5. Holmquist's buffer in plastic jar at $65^{\circ} \mathrm{C}$ for $1 \mathrm{~h}$.

6. $3 \%$ unfiltered Giemsa (Merck) in phosphate buffer $\mathrm{pH} 6.9$, for $10-15 \mathrm{~min}$,

7. Rinse with washing bottle, keep $10 \mathrm{~min}$ in aq. dest., and rinse again with washing bottle. Dry in air.

8. Study uncovered. Immersion oil can be removed with xylene. If satisfactory, seal.

9. If bands are present, but euchromatin too dark: Wash with the buffer pH 6.9 (or its water dilution 1:1) checking under microscope. Rinse in aq. dest. $2 \times$, dry, and seal.

10. Any other banding failure: reband until satisfactory. 